\title{
Model-based reconstruction and projections of soil moisture anomalies and crop losses in Poland
}

\author{
Mikołaj Piniewski ${ }^{1,2}$ (D) Paweł Marcinkowski ${ }^{1} \cdot$ Joanna O'Keeffe $^{1} \cdot$ Mateusz Szcześniak $^{1} \cdot$ Anna Nieróbca $^{3}$. \\ Jerzy Kozyra ${ }^{3} \cdot$ Zbigniew W. Kundzewicz $^{2,4} \cdot$ Tomasz Okruszko $^{1}$
}

Received: 24 November 2018 / Accepted: 15 January 2020 /Published online: 1 February 2020

(C) The Author(s) 2020

\begin{abstract}
Evidence shows that soil moisture (SM) anomalies (deficits or excesses) are the key factor affecting crop yield in rain-fed agriculture. Over last decades, Poland has faced several major droughts and at least one major soil moisture excess event leading to severe crop losses. This study aims to simulate the multi-annual variability of SM anomalies in Poland, using a process-based SWAT model and to assess the effect of climate change on future extreme SM conditions, potentially affecting crop yields in Poland. A crop-specific indicator based on simulated daily soil moisture content for the critical development stages of investigated crops (winter cereals, spring cereals, potato and maize) was designed, evaluated for past conditions against empirical cropweather indices (CWIs), and applied for studying future climate conditions. The study used an ensemble of nine bias-corrected EURO-CORDEX projections for two future horizons: 2021-2050 and 2071-2100 under two Representative Concentration Pathways: RCP4.5 and 8.5. Historical simulation results showed that SWAT was capable of capturing major SM deficit and excess episodes for different crops in Poland. For spring cereals, potato and maize, despite a large model spread, projections generally showed increase of severity of soil moisture deficits, as well as of total area affected by them. Ensemble median fraction of land with extreme soil moisture deficits, occupied by each of these crops, is projected to at least double in size. The signals of change in soil moisture excesses for potato and maize were more dependent on selection of RCP and future horizon.
\end{abstract}

\section{Introduction}

Crop yield varies in time and space, being influenced by multiple factors, including weather, soil, pests and diseases, fertilization, irrigation, as well as other agronomy management practices. In rain-fed agricultural systems, weather variability

Electronic supplementary material The online version of this article (https://doi.org/10.1007/s00704-020-03106-6) contains supplementary material, which is available to authorized users.

Mikołaj Piniewski

mpiniewski@levis.sggw.pl

1 Department of Hydrology, Meteorology and Water Management, Warsaw University of Life Sciences, Nowoursynowska Street 166, 02-787 Warsaw, Poland

2 Potsdam Institute for Climate Impact Research (PIK), Member of the Leibniz Association, P.O. Box 6012 03, 14412 Potsdam, Germany

3 Institute of Soil Science and Plant Cultivation-State Research Institute, Czartoryskich street 8, 24-100 Puławy, Poland

4 Institute for Agricultural and Forest Environment of Polish Academy of Sciences, Bukowska street 19, 60-809 Poznań, Poland is the key factor controlling crop growth and yields. For example, on average, some $44 \%$ of the temporal variability of wheat yield in four largest EU wheat producers, i.e. France, Germany, UK and Poland, can be explained by climate variability (Ray et al. 2015). Schauberger et al. (2016), who for the first time systematically collected global-scale evidence on the drivers of change in wheat, maize and rice physiological processes and yields, reported that the soil moisture (SM) followed by temperature and atmospheric $\mathrm{CO}_{2}$ concentrations were the foremost among 130 identified factors. In contrast to weather variables, soil moisture data have "memory", thus providing an integrated information on past meteorological conditions (Samaniego et al. 2013; Urban et al. 2015). As shown in the recent study of regression models of maize yields in Germany (Peichl et al. 2018), accounting SM improved prediction capability for all investigated model configurations compared to regressions based only on meteorological variables. Similarly, simulated SM deficit indices had higher correlations with crop yields than conventional precipitationbased drought indices in studies in Texas (for wheat-see Narasimhan and Srinivasan 2005) and in the Upper Mississippi River Basin (for maize and soybean-see Li 
et al. 2017). In summary, evidence shows that soil moisture should be the primary variable of interest in the context of spatio-temporal crop yielding analysis.

The relationship between crop yield and SM is highly complex. Both deficit and excess of soil moisture can negatively affect crop yield, although their role varies with plant type, climate, soil and phenological stage during crop growth. For example, in the USA, on average, $41 \%$ of crop losses were found to be caused by drought, as compared to $16 \%$ caused by water excess (Boyer 1982). Two main effects of limited SM are decreased plant water uptake and plant tissue dehydration reducing shoot and root growth, as well as membrane integrity (Wang et al. 2016). Earl and Davis (2003) reported that the development and growth of maize and other grain crops is negatively influenced by droughts by reducing three main quantities: (1) canopy absorption of incident photosynthetically active radiation, (2) radiation use efficiency and (3) harvest index. The critical role of water supply at high temperature for US maize, soybean and wheat yields was shown in a study employing nine process-based crop models (Schauberger et al. 2017). Over-supply of soil water (in the extreme case, soil waterlogging) leads to reduction of oxygen transport rates in the soil, with adverse consequences to root metabolism and delaying root development (Raes et al. 2006; Wang et al. 2016). Even short periods of waterlogging (e.g., 3 days) can have considerable influence on wheat growth (Malik et al. 2002). Furthermore, excess wetness is known to hamper certain farming practices (e.g. planting, tillage, harvest) due to problems with access by heavy machinery, particularly for poorly drained soils in high precipitation regimes (Brown 2017; Urban et al. 2015). Rosenzweig et al. (2002) concluded that ignoring crop damages caused by soil moisture excess may lead to overestimates of the positive effects of "wet" climate change scenarios on rainfed agriculture around the world.

Increasing losses in yields caused by extreme weather events in recent decades have been also observed in Poland, predominantly caused by droughts (Górski et al. 2008; Kozyra et al. 2012; Łabędzki 2007). Indeed, Poland is a country where extreme events affect yields to a large extent: for instance, adding the effect of extreme events to regression models explained more than $44 \%$ of the interannual variability of spring barley yield in Poland (Pagani et al. 2017). Górski et al. (2008) developed a catalogue of weather extremes leading to crop losses visible at the national scale, reporting 10 major drought years and 4 years with excessive SM during the interval from 1955 to 2006. Since then, major droughts leading to yield decreases occurred also in 2008 (Kozyra et al. 2012) and 2015 (Hoy et al. 2017; Van Lanen et al. 2016). The most recent crop monitoring bulletin for the year 2018 from the European
Commission (JRC MARS Bulletin 2018 ${ }^{1}$ ) reported that the crop water requirements were not supported by sufficient SM, affecting crop growth just before flowering of winter crops. Extreme drought conditions in Poland in 2018 were also reported by the remote sensing products ${ }^{2}$ and the state monitoring of agricultural drought ${ }^{3}$ that announced $58 \%$ of communes with spring cereal yields being threatened by drought. Recent assessments of drought indices in Poland (Somorowska 2016), Czech Republic, Slovakia and northern Austria (Trnka et al. 2016) revealed an increased intensity and spatial coverage of droughts in all these countries. Excessive soil moisture (together with cool weather and the scarcity of sunshine) contributed to huge yield decreases of all crops in 1980, and to a smaller extent in 1997 (Górski et al. 2008). In contrast to droughts, no studies were found suggesting a positive trend in the occurrence of excessive soil water conditions over past decades. Overall, some Polish authors (Kalbarczyk 2004; Koźmiński 1996) underline the fact that SM content is the most comprehensive factor affecting crop yield variability, since it integrates in itself the effects of particular weather variables as well as edaphic factors.

Given the fact that the most recent EURO-CORDEX-based climatic projections for Poland suggest a ubiquitous warming and a fairly consistent (across different ensemble members) increase in the growing season precipitation (Piniewski et al. 2017a), there is no immediate and obvious answer to the question concerning the future outlook on the two extreme states of soil moisture conditions in Poland leading to crop losses. The reason is that the hydrological response to this type of "warmer and wetter" forcing is generally complex: precipitation- and runoff-based indicators show positive trends, whereas the standardized precipitation-evapotranspiration index (SPEI) shows a negative trend (Meresa et al. 2016). At the larger, continental scale, a recent assessment suggests an increased soil moisture drought hazard in Europe under the $3 \mathrm{~K}$ warming in Europe (Samaniego et al. 2018), but there is a lack of similar studies at the national scale in Poland.

The objectives of this study are as follows: (1) to simulate historical, multi-annual variability of soil moisture anomalies (deficits and excesses) that could lead to potential crop yield reductions in Poland, and (2) to assess the effect of climate change on future extreme SM conditions, potentially affecting crop yields in Poland. To this end, a large-scale hydrological model SWAT is employed, forced with two types of climate data sets: (1) a high-resolution observational data set, in order

\footnotetext{
${ }^{1}$ https://ec.europa.eu/jrc/sites/jrcsh/files/jrc-mars-bulletin-vol26-no06.pdf (last accessed on 20 November 2018)

${ }^{2} \mathrm{http}: / /$ www.igik.edu.pl/en/a/drought-2018 (last accessed on 20 November 2018)

${ }^{3} \mathrm{http}: / /$ www.susza.iung.pulawy.pl/en/komentarz/05/ (last accessed on 20 November 2018)
} 
to study historical spatio-temporal changes; and (2) an ensemble of nine bias-corrected EURO-CORDEX projections for two future horizons: 2021-2050 and 2071-2100 under two Representative Concentration Pathways: RCP4.5 and 8.5. Four crops or groups of crops, important for food and animal production in Poland, were investigated: winter cereals, spring cereals, potato and maize. A crop-specific indicator based on simulated daily soil moisture content for the critical development stages of investigated crops was designed, evaluated for the past conditions against empirical weather-related yield reduction data, and applied for studying future climate conditions.

\section{Materials and methods}

\subsection{Study area}

Poland is predominantly a lowland country, whose largest part belongs to the Central European Plain and the Eastern Baltic Plain. Mountainous areas stretch only along the southern border of the country. Sands and loamy sands are two most frequent soil types. The climate of Poland is temperate with cold winters (particularly in the east) and warm summers. Precipitation varies both in space and time, with the lowest values of 500-550 mm per year in the central part of Poland. On the seasonal basis, most of precipitation falls as rain in summer; however, it is mainly winter and early spring snowmelt that helps to replenish soil moisture, recharge groundwater aquifers and increase river flows.

This study is devoted to the agricultural land within the Polish parts of two largest river basins in Poland, the Vistula and Odra basins (VOB). Using hydrological boundaries results from making use of the hydrological model in this study (cf. Sections 2.2-2.3). The Polish part of the VOB covers $87 \%$ of the Polish territory, whereas agricultural land within the VOB constitutes $89 \%$ of the total agricultural land in Poland. The remaining 11\%, particularly in the northern area close to the Baltic Sea coast, is characterized by a low share of arable land, a high share of fallow land and waste land, and a low index of quality of agricultural production space (Bański 2010). Therefore, the area under investigation in this study is well representative for the Polish agriculture as a whole.

More specifically, this study deals with important crops for Polish agriculture: winter and spring cereals, potato and maize. As of 2002 (Agricultural Census data), they were grown at $86 \%$ of cultivated area in Poland, of which cereals occupied $74 \%$. Winter cereals were most frequently cultivated in the central, southern and western parts of the country, whereas spring cereals in the northern and north-eastern parts (Fig. 1 of Online Resource 1). Potato was cultivated most frequently in the south-eastern, while maize in the southwestern part of Poland.
Crop production in Poland has undergone dynamic changes over past few decades. According to the Food and Agriculture Organization (FAO) data, agricultural area in Poland has shrunk from $63.1 \%$ in 1975 to only $48.6 \%$ of land area in 2012. Out of analysed crops, potato was affected most, with an areal decline by an order of magnitude within the interval from 1975 to 2015 (Fig. 1a), due to manifold reasons: giving up cultivation in numerous small-sized farms, gradual change of preferences of Polish consumers and decreasing role of potatoes as animal feed (Bański 2010). Changes in the area sown by cereals were more complex, due to different directions of changes in particular species: e.g. rapidly decreasing acreage of rye and oats on the one hand and a growing popularity of triticale and mixed grains on the other hand. Maize, in contrast, was virtually absent until mid-1990s and its popularity has been steadily growing since then.

In general, crop yields were increasing in the 1975-2015 interval (Fig. 1b), although the pattern of change has been quite complex due to several factors (e.g. economic transformation, technological and biological progress, soil acidification). The yield gap in Poland is higher than in neighbouring countries: much higher than in Germany, but also higher than in Czech Republic and Slovakia, as simulated for wheat and rapeseed by Królczyk et al. (2014). Clearly visible, sharp, yield declines in some of the years $(1992,1994,2006,2015)$ are a consequence of adverse weather conditions, that will be discussed in detail in Section 2.5.

\subsection{The SWAT model}

The SWAT (Soil and Water Assessment Tool) model is a semidistributed, process-based, hydrological model that simulates the movement of water, sediment and nutrients on a catchment scale with a daily time step (Arnold et al. 1998). In SWAT, the river basin is partitioned into sub-basins based on the Digital Elevation Model (DEM). The smallest unit of discretization is a unique combination of land use, soil and slope overlay referred to as a hydrologic response unit (HRU). Runoff is predicted separately for each HRU, then aggregated to the subbasin level and routed through the stream network to the main outlet to obtain the total runoff for the river basin.

The main variable of interest in this study, i.e. the soil moisture content, is affected by several other important hydrological variables in SWAT. Precipitation is divided into surface runoff and infiltration using the modified Soil Conservation Service (SCS) curve number method. Water can be transported out of the soil column via three pathways: evapotranspiration (ET), lateral flow and percolation to the groundwater aquifer. Crop growth (which includes crop yield) is the major component of SWAT. The crop growth component is based on a simplified version of the EPIC model (Williams et al. 1982), whereby phenological plant development is based on daily accumulated heat units. Crop growth, ET and soil 
Fig. 1 Changes in cultivated areas (a) and yields (b) of selected crops in Poland over the interval from 1975 to 2015 according to GUS (Central Statistical Office). Maize yield data start in 1992. In this figure, winter cereals are represented by winter wheat and rye, and spring cereals by spring wheat and spring barley. As of 2015 , winter wheat and rye constituted $63 \%$ of all winter cereals, whereas spring wheat and spring barley $-40 \%$ of spring cereals a Cultivated area of selected crops in Poland

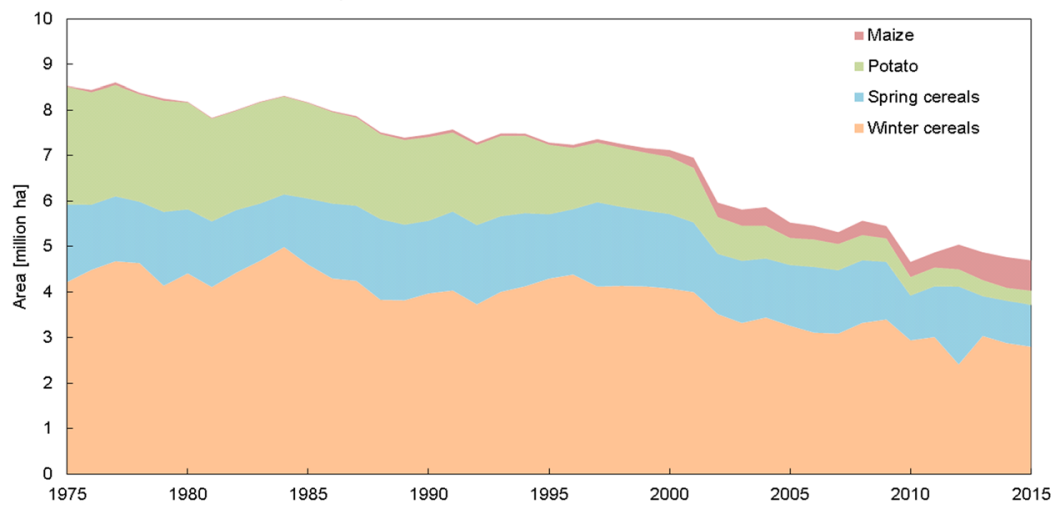

b Average yields of selected crops in Poland

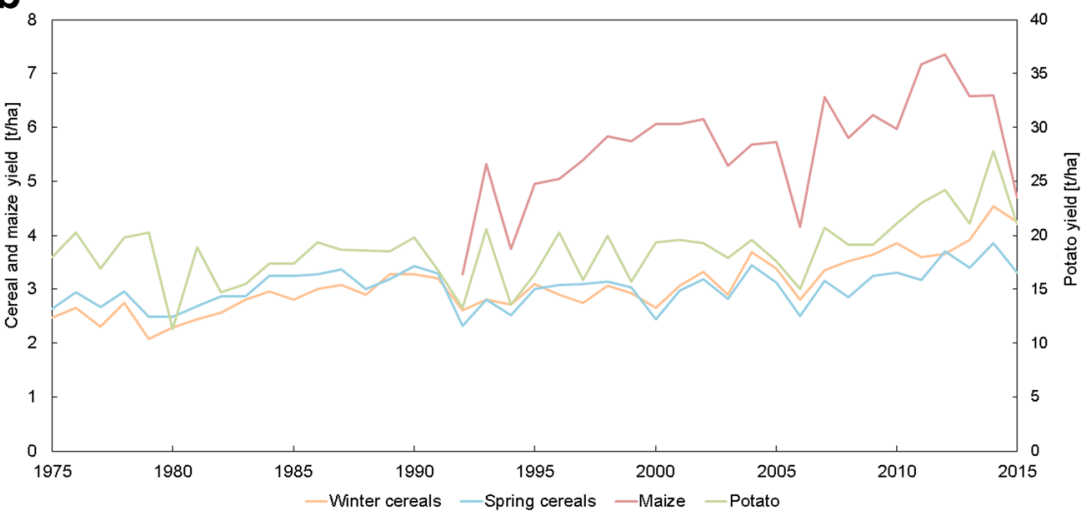

moisture are all strongly interlinked in SWAT: crop growth not only ties ET in the hydrologic budget, but it also affects soil moisture. Water stress, together with heat, nitrogen and phosphorus stresses are the principal stress factors simulated in SWAT. Equations governing all these processes are explained in Neitsch et al. (2011).

Although SWAT simulates crop growth and yield, the lack of access to reliable, detrended, observed yield data at sufficient spatial resolution over a long time span made it impossible to carry out calibration and validation of crop yields. Polish yield data are non-linear, non-stationary and highly spatially variable due to various, previously discussed factors (cf. Fig. 1b). Furthermore, spatial reporting units changed, following the change of administrative division of Poland in 1999. All this makes detrending of Polish yield time series a complex task (cf. Lu et al. 2017). However, as demonstrated by Srinivasan et al. (2010), even an uncalibrated SWAT model can give reasonable predictions of crop yields for a large river basin, which suggests that not performing calibration is not necessarily a problem. For the above reasons, in this paper we use simulated SM data in order to develop proxy indicators of the occurrence of weather-related crop losses in Polish conditions. Previous SWAT applications in this context (Narasimhan and Srinivasan 2005; Wang et al. 2016) as well as various empirical studies linking SM and crop yield for rain-fed agricultural systems in temperate climates
(Kalbarczyk 2004; Koźmiński 1994; Peichl et al. 2018) provide a solid support for such an approach.

\subsection{Modelling data and workflow}

In this study, we used previously developed SWAT model setup of the VOB for the historical period (Piniewski et al. 2017c), as well as SWAT simulations forced with climate change scenarios (Piniewski et al. 2017b, d). The input soil map was reclassified from the source map containing soil texture data in the scale 1:500,000 obtained from the Institute of Soil Science and Plant Cultivation in Puławy (IUNG-PIB). EPIC-based plant growth component parameters were set as described in Marcinkowski and Piniewski (2018). Climate change effect simulations originated from the CHASE-PL Climate Projections-Gridded Daily Precipitation and Temperature $5 \mathrm{~km}$ data set (CPLCPGDPT5), i.e. projections from an ensemble of nine EUROCORDEX regional climate models for three time horizons (1971-2000, 2021-2050, 2071-2100) and two RCPs (4.5 and 8.5) (Mezghani et al. 2017). A short summary of climate projections is provided in Appendix A (Tables 2 and 3).

Soil moisture content simulated by SWAT is expressed in millimetre of water in a soil column. Such data cannot be directly analysed in terms of spatial drought characteristics due to variation in soil retention parameters among different 
soil classes as well as to different climatologies within the large domain. Thus, all SM data were normalized by the total available water capacity of each soil column and expressed in dimensionless units. Normalized data allow for better spatial comparison of extreme conditions across the study domain (Andreadis et al. 2006).

Outputs from HRUs related to land cover classes representing four crops, i.e. winter cereals (represented in the model setup by winter wheat), spring cereals (represented by spring barley), potato and maize, were extracted for analysis in this study. Furthermore, only HRUs located inside Poland and lying below $500 \mathrm{~m}$ a.s.l. were included. In result, 6540 HRUs occupying 105.4 million ha were left for analyses: 2357 (50.2 million ha) for winter cereals, 2043 (37.2 million ha) for spring cereals, 1514 (14.1 million ha) for potato and 626 (3.9 million ha) for maize. Spatial distribution of these four crops in the land cover map used in the model setup followed the one presented in Fig. 1 of Online Resource 1. It should also be noted that all these crops were non-irrigated in the model setup - which is consistent with the fact that existing irrigation systems in Poland are used to a very small extent.

\subsection{Development stages with critical water requirements}

In this study, whenever we write about the weather-related crop losses, we refer to those losses that originate from either drought conditions or from excessive moisture conditions in soils. In other words, crop losses that are attributed to other types of weather variables, such as temperature (e.g. heat waves or cold spells), sunshine duration, snow cover, etc., are not within the scope of this study. It is clear however, that some types of weather conditions are inter-related, e.g. droughts can be accompanied by heat waves.

Crop water requirements vary with plant development and each crop has its specific, critical stage, during which its water requirements are the highest throughout the growing season. Inappropriate soil moisture conditions during these periods are typically the most harmful to plants, and can lead to severe yield damages. The knowledge of these crop-specific stages gathered in this section is required for calculation of SM indicators in historical simulations and climate change projections.

Table 1 shows the approximate dates of the critical development stages for four crops selected in this paper. Table 1 also includes dates sowing and harvesting dynamically simulated by SWAT with the help of the heat unit-based scheduling (cf. Marcinkowski and Piniewski 2018). The ranges in those dates of about 30 days reflect inter-annual and spatial climatic variability. The dates of development stages with critical moisture requirements were estimated based on literature on plant physiology and agronomy. They are given both as dates and in relation to specific crop development stages.

\subsection{Cumulative soil moisture deficit and excess indicators}

In order to evaluate the SWAT model in terms of its simulation of extreme soil moisture conditions leading to crop yield reductions, we developed indicators based on time series of normalized SM content, for the HRU level, obtained from the SWAT model run forced with observed climate data (cf. Section 2.3). The indicator was supposed to give a value for each HRU (i.e. crop/soil/slope/sub-basin combination) and each year of simulation, describing the magnitude of departure from average SM conditions during the critical development stages (cf. Table 1) in this HRU. The focus on critical stages was motivated by literature indicating the importance of appropriate moisture conditions in these intervals for plant development (cf. Section 2.4).

In Poland, similar to Germany (Samaniego et al. 2013), the long-term mean and standard deviation of the normalized SM

Table 1 Approximate sowing dates, harvest dates and development stages with critical moisture requirements for four selected crops grown in the baseline climate in Poland

\begin{tabular}{|c|c|c|c|c|c|}
\hline Crop & Sowing date & Harvest date & $\begin{array}{l}\text { Critical stage for soil } \\
\text { moisture requirements }\end{array}$ & Name of development stage & Source \\
\hline Winter wheat & 10 Sep-5 Oct & $10 \mathrm{Jul}-10 \mathrm{Aug}$ & 10 May-5 Jul & $\begin{array}{l}\text { Inflorescence emergence } \\
\left(50^{\mathrm{a}}\right) \text {-milk stage }(75)\end{array}$ & $\begin{array}{l}\text { Nix and Fitzpatrick (1969); Hane and } \\
\text { Pumphrey (1984); Farooq et al. } \\
\text { (2014); Grzebisz (2011a) }\end{array}$ \\
\hline Spring cereals & $20 \mathrm{Mar}-15 \mathrm{Apr}$ & 1 Aug-30 Aug & 20 May-15 Jul & $\begin{array}{l}\text { Inflorescence emergence } \\
\quad(50)-\text { milk stage (75) }\end{array}$ & $\begin{array}{l}\text { Hane and Pumphrey (1984); } \\
\text { Farooq et al. (2014); Martyniak } \\
\text { (2012); Grzebisz (2011a) }\end{array}$ \\
\hline Potato & 10 Apr-10 May & $10 \mathrm{Sep}-10$ Oct & 15 Jun-15 Aug & $\begin{array}{l}\text { Tuber initiation (40)-tuber } \\
\text { formation (49) }\end{array}$ & $\begin{array}{l}\text { Van Loon (1981); Grzebisz (2011b); } \\
\text { Kalbarczyk (2004) }\end{array}$ \\
\hline Maize & 20 Apr-10 May & $20 \mathrm{Sep}-10 \mathrm{Oct}$ & 15 Jun-31 Jul & Boot stage (41)-milk stage (73) & McWilliams (2002); Grzebisz (2011a) \\
\hline
\end{tabular}

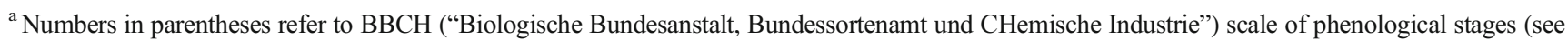
Meier et al. 2009) 
indicate a clear seasonality, with wet and quite stable conditions in winter and drier but highly variable conditions in summer (Somorowska 2017). Due to this strong seasonality, it was decided that thresholds defining the occurrence of SM deficit or excess conditions should be time dependent, rather than constant. Example threshold curves for deficit and excess conditions are shown in Fig. 2. Their calculation (cf. Appendix B) accounts for variable water retention properties of Polish soils. The motivation for including these "soil factors" is that very light soils should be the most vulnerable to droughts and the least vulnerable to water excess conditions, while heavy soils on the contrary (Table 4).

Figure 2 schematically illustrates the method of calculation of both considered indicators: cumulative soil moisture deficit $(C S M D)$ and excess (CSME). Both annual indices measure the negative/positive anomalies of SM content from daily varying thresholds. It should be noted that both persistence of extreme conditions in soils and the actual rate of departure from predefined thresholds influence the final value of both indicators. The term cumulative reflects the fact that the indicators accumulate values within the plant development periods with critical SM requirements. In low flow hydrology, the CSMD analogues are called drought volume or severity (although they are typically calculated using a fixed threshold). Calculation is restricted to critical development stages, since, as shown in the studies employing SWAT for development of agricultural drought indices (Li et al. 2017; Narasimhan and Srinivasan 2005), SM indices have the highest correlation with crop yields when calculated for those critical stages. Interpretation of CSMD and CSME is straightforward: the higher the values, the more extreme SM conditions during critical development stages, and hence, the more likely crop yield losses.

The annual time series of CSMD and CSME were calculated for the whole historical simulation period from 1954 to 2013. Values of CSMD were calculated for all HRUs covered by any of four analysed crops, while CSME only for potato and maize HRUs due to the fact that cereals are less affected by excessive SM.

\subsection{Crop-weather indices}

In this study, we have used an indirect method of evaluation of extreme SM simulations in SWAT. It is based on the so-called crop-weather indices (CWIs), constructed on the basis of empirical-statistical models (using modified multiple regression) of weather-yield relationships (Górski 2007; Kozyra et al. 2012). The CWIs are station-based, crop-specific indices that quantify the effects of meteorological conditions on crop yield in a given location. The value of CWI equal to $100 \%$ refers to average yield, whereas a deviation by $X \%$ below 100

a

Soil moisture deficit, spring cereals

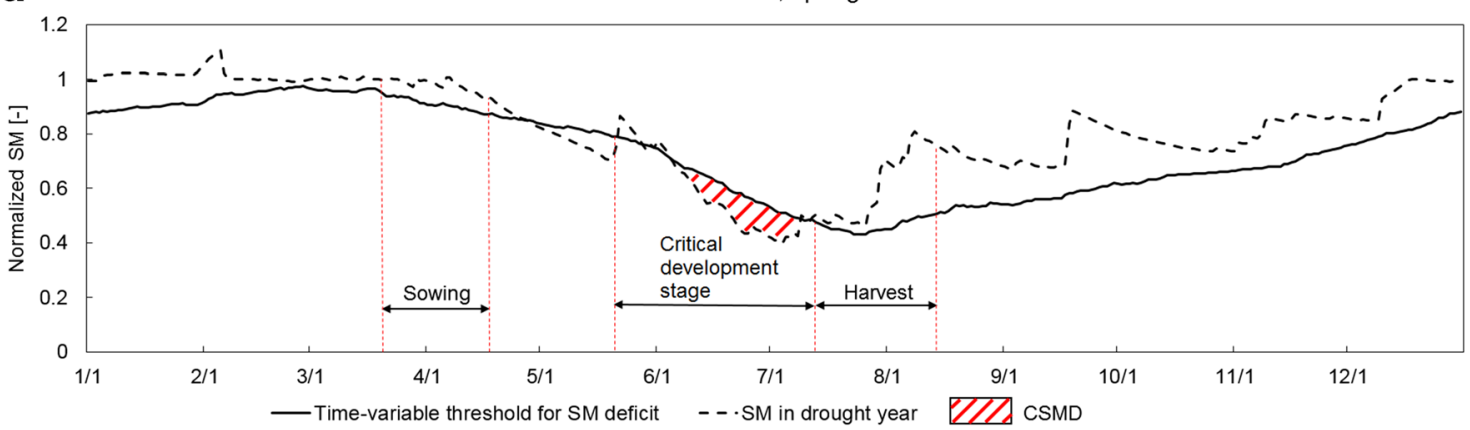

b Soil moisture excess, maize

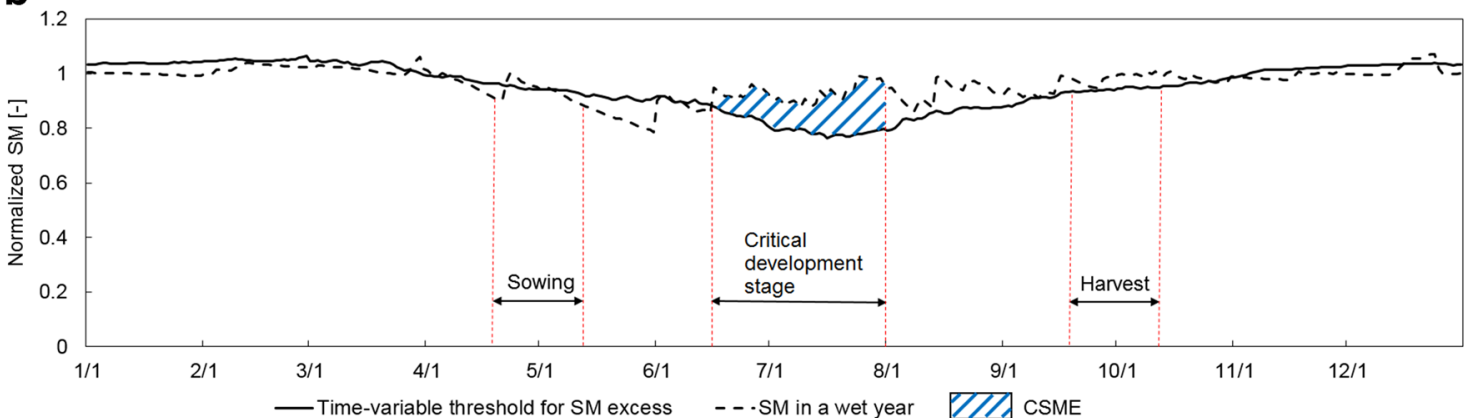

Fig. 2 Schematic illustration of cumulative soil moisture deficit (CSMD for spring cereals, panel a) and cumulative soil moisture excess (CSME for maize, panel b) indicators. Graphs show the dynamics of daily normalized SM data $\left(z_{i, j}\right)$ in an example drought (a) and wet (b) year versus time-variable thresholds of deficit $\left(T V T_{i}^{-}\right)$and excess $\left(T V T_{i}^{+}\right)$ conditions. Hatched red area between $z_{i, j}$ and $T V T_{i}^{-}$within the development stage with critical SM requirements determines the value of $C S M D_{i}$ in a given drought year $i$. Hatched blue area between $z_{i, j}$ and $T V T_{i}^{+}$within the critical development stage determines the value of $C S M E_{i}$ in a given wet year $i$. See Appendix B for equations defining aforementioned symbols 
can be interpreted as the expected reduction in yield due to weather conditions (Górski 2007). Extremely low values of CWIs can be interpreted as proxies for extremely low crop yields, and can be used for spatio-temporal evaluation of extremely low soil water content simulations from SWAT.

The CWIs were calculated for four investigated crops: winter cereals (represented by winter wheat), spring cereals (the average of indices for spring barley and oats), potato and maize, for the time period from 1972 to 2015 and for 35 climate stations run by the Institute of Meteorology and Water Management-National Research Institute (IMGWPIB), located in the VOB area (cf. Fig. 1 of Online Resource 1). For each crop, we have identified years with spatially averaged CWI values below $90 \%$ and, using available literature on historical crop damages and droughts in Poland and Europe (Farat et al. 1998; Górski et al. 2008; Kalbarczyk 2004; Kozyra et al. 2012; Koźmiński and Michalska 1995; Somorowska 2016; Spinoni et al. 2015; Zawadzki and Mierosławska 1993), we identified either deficit or excessive SM conditions as the main driver of low CWI. Calculated CWIs will be presented alongside the presentation of SWATbased SM validation in the Results section.

\subsection{Climate change impact indicators}

In order to assess the effect of climate change on SM anomalies leading to potential crop yield decreases, we have calculated the annual time series of CSMD and CSME for all climate change scenarios. Calculations of indices were based only on the climate model-driven data for both future horizons and control period, so as to remove the potential biases of the climate models. Two important changes were made with respect to the calculation method, compared to that reported in Section 2.6.

1. Following Karlsson et al. (2015), the same values of timevarying thresholds $T V T_{i}^{-}$and $T V T_{i}^{+}$(Eqs. (B.1), (B.2)) were used for calculation of indices for historical and future periods. This was done in order to compare future results with a known period of reference (Karlsson et al. 2016) and thus, to quantify the pure effect of climate change.

2. For each future scenario, the dates of the critical development stages, $C D S$, used in Eqs. (B.3, B.4) and listed in Table 1 were adjusted for the effect of warming on advancement of plant phenological stages. The adjustment constants were based on projected changes in sowing and harvesting dates simulated by SWAT (Marcinkowski and Piniewski 2018). In consequence, $C D S$ timing was advanced by a number of days ranging between 8 (ensemble mean across all crops for RCP4.5 NF) to 24 (ensemble mean across all crops for RCP8.5 FF).
In our assessment of climate change impact on weatherrelated crop losses, we want to focus on the most severe events of deficit or excessive SM in the multi-annual projection periods. Previous studies suggest that, historically, the frequency of drought events in Poland is higher than the frequency of SM excess events leading to crop losses. Therefore our indicator of severity of SM anomalies in a given climate scenario was based on the average of the four largest annual CSMD values and two largest CSME values. Positive values of the differences between future horizons and control period can be interpreted as a projected growing hazard of crop losses due to unfavourable SM conditions (too dry in case of CSMD and too wet in case of CSME), whereas their negative values - as decreasing hazard.

The second type of assessment concerned the area under deficit/excess conditions. For each climate model, RCP, horizon combination, each crop and each year of the simulation period, we calculated the fraction of total area occupied by a given crop that is under deficit or excess conditions in a given year. Different values of thresholds for deficit (CSMD) and excess (CSME) conditions were tested in order to evaluate different levels of extremity.

\section{Results}

\subsection{Simulation of historical soil moisture anomalies}

Analysis and interpretation of the computed time series of CWI values enabled to identify observation-based weatherrelated crop losses in Poland. In the case of droughts, the most frequent crop losses occurred for spring cereals: 1979, 1992, 1994, 2000, 2006 and 2008. Winter cereals experienced losses due to droughts in 4 years: 1992, 2000, 2003 and 2006, whereas potato and maize in 3 years: 1992, 1994 and 2006. There were only 2 years for which low CWIs were attributed to excessive wetness (1980, and to a lesser extent 1997) for potato and 1 year (1980) for maize.

In the next step, SWAT-based CSMD and CSME values were compared to CWIs for selected, crop-specific drought and SM excess years. To this end, for each of 35 stations we assigned SWAT sub-basins lying in the distance below $20 \mathrm{~km}$ and presented the results as box plots summarizing spatial variability (Fig. 3). The results demonstrate that SWAT was capable of capturing SM extremes that lead to crop yield reductions. For each crop, CSMD and CSME values for identified years were several times higher from corresponding values in remaining, non-extreme years. In the majority of cases, both CSMD/CSME and CWI values show large spatial variability, suggesting that crop losses affected only parts of the country. However, the rank of years with extreme crop losses was not always the same in SWAT and CWIs. For winter cereals, CWIs suggested that 2006 was the year with 

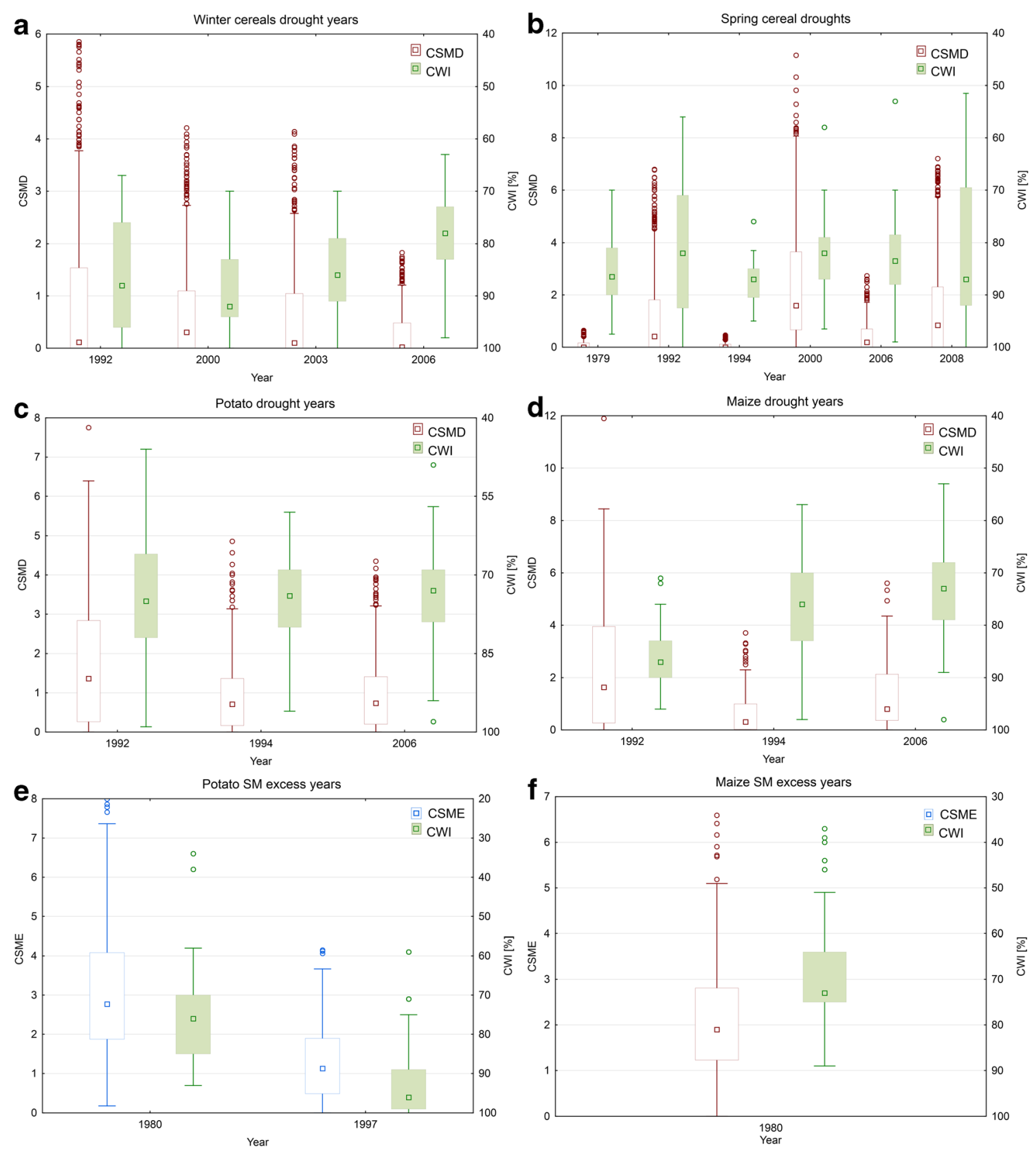

Fig. 3 Comparison of simulated cumulative soil moisture deficit $\left(C S M D_{j}\right.$, panels a-d, all crops) and excess $\left(C S M E_{j}\right.$, panels e, f, potato and maize) indicators from SWAT with station-based crop-weather

indices (CWIs) for identified years with SM deficits and excesses. The box plots were calculated across all HRUs lying in the $20 \mathrm{~km}$ proximity from CWI stations for CSMD and CSME, and across all stations for CWIs

the most severe losses, while the estimates from SWAT showed that it was 1992. For spring cereals, there were 2 years with particularly high yield reductions according to CWIs: 1992 and 2008. Although these years were associated with high CSMD values, even higher values were simulated for year 2000. Both model-based and empirical prediction showed that 1992 was the year with the highest droughtrelated losses for potato. In contrast, for maize, year 2006 was characterized by the highest losses based on CWI values, whereas SWAT predicted the highest losses for year 1992. Finally, in the case of SM excess-related losses, there was an

agreement between CSME and CWI values that the most severe potato and maize losses occurred in 1980.

Spatial variability of CSMD and CSME values in years with the most severe SM deficits (2 years with highest losses for all crops) and excesses (1 year for potato and maize) was illustrated in Fig. 4. Comparison of spatial patterns between simulated SM indices and crop-weather indices shows a very good agreement for spring cereals in two drought years (1992, 2008) in which these crops suffered from the highest yield decreases. Maps show that the highest SM deficits and yield reductions in these years occurred in north-western Poland. 
Fig. 4 Maps of SWAT-based estimates of the cumulative soil moisture deficit (CSMD) and excess (CSME) indicators for selected years with extreme droughts (brown) and extreme water excess (blue) for four analysed crops. For comparison, maps of station-based cropweather indices (CWI, shown as points) are also presented. White spaces are related to low fractions of a given crop in particular areas

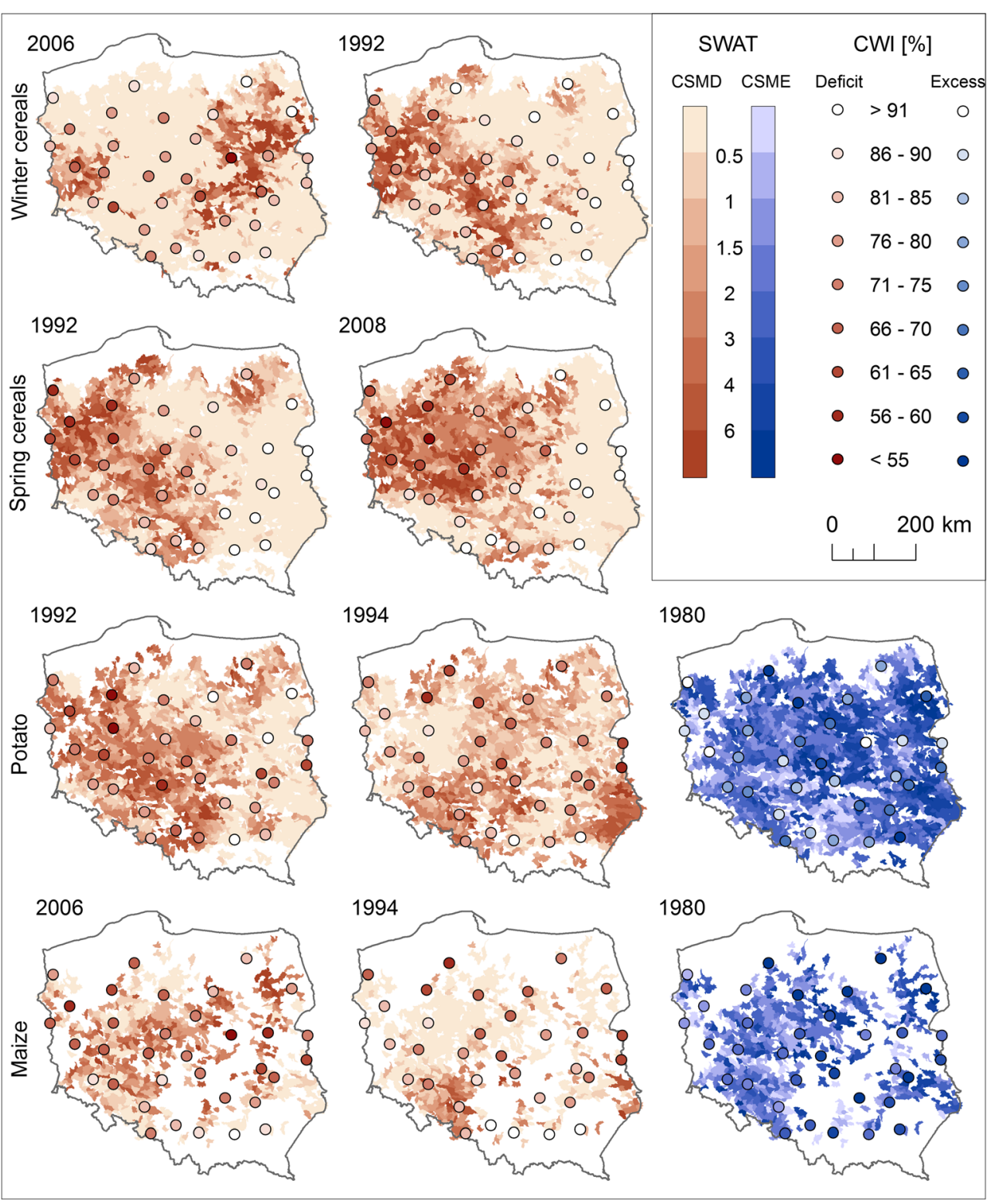

They also agree that, in both years, neither moisture deficits nor yield reductions occurred in eastern Poland. There is a moderately good agreement between spatial distribution of CSMD and CWI for the 2006 and 1992 droughts for winter wheat. In contrast, the agreement is rather low for maize in 2006 and 1994 as well as for potato in 1994. However, as for 2006, the comparison of CSMD for winter wheat with the map of mean June soil water storage (SWS) derived from the Global Land Data Assimilation System (GLDAS) provides good results, and the same holds true for the comparison of CSMD for potato and maize with July/August GLDAS SWS (Somorowska 2017).

In the case of SM excess for potato and maize, two maps for year 1980 shown in Fig. 6 present rather poor spatial agreement between SWAT and CWI. For this reason, we compared these maps with the map of excessive SM for potato in year 1980 shown in Kalbarczyk (2004) (Fig. 2 of Online Resource 1). In that case, spatial agreement was much better. The map of Kalbarczyk (2004) confirmed that excessive moisture conditions in the summer of 1980 covered practically the entire country (as in SWAT, in which CSME exceeded the value of 1 in more than $80 \%$ of the area), but the most extreme conditions with prolonged moisture excess (and CSME exceeding 4) occurred in central Poland.

\subsection{Projections of SM deficits and excesses leading to crop yield losses}

\subsubsection{Changes in the severity of SM anomalies}

The results showing spatially averaged effect of climate change on CSMD and CSME are presented as box plots 
representing climate model spread for each crop, RCP and future horizon. They present a large uncertainty (Figs. 5 and 6). Considerable spread can be noted for almost all cropscenario combinations. The largest inconsistency can be observed for moisture deficits of winter cereals, for which a roughly similar number of model runs shows a decrease and an increase, regardless of RCP and future horizon. A different situation occurs for spring cereals, potato and maize: here, despite large spread, projections generally show increasing extreme moisture deficits. The largest median increase is projected for RCP4.5 in the far future, when it reaches approximately the value of 1 for each of these crops.

The variability of changes in CSME for potato and maize is overall lower than that of CSMD (Fig. 6). With an exception of RCP8.5 in the far future, for other scenarios extreme soil moisture excesses are projected to increase for the majority of model runs. This means that in many cases SWAT projects an increase in both deficits and excess moisture conditions in the future. Under RCP8.5, in the far future, the magnitude of changes is lower than in other cases, and, for potato, decreases are prevailing. For maize, changes in both directions are projected.

\subsubsection{Changes in the area affected by SM anomalies}

The area affected by SM deficits (measured as a fraction of total area cultivated by a particular crop) for the multi-annual "extreme" year (i.e. 95th percentile; Fig. 7) is expected to change between historical and future horizons under both RCPs. More detailed results presenting inter-annual changes in this variable for all individual climate model runs are shown in Figs. 3-5 of Online Resources 1. For illustrative purposes, thresholds equal to 3 and 2 were selected to define years with deficits and excesses, respectively. It was also verified that the choice of thresholds does not affect general conclusions. The area affected by SM deficits is projected to increase for spring cereals, potato and maize according to the majority of simulation runs for different RCP-horizon combinations. Ensemble median fraction of land with SM deficits, occupied by each of these crops, is projected to at least double in size. In all cases, at least two thirds of the ensemble members suggest that the area would increase in the future, and in some cases (e.g. potato under both RCPs in the far future) all nine model runs agree on the simulated increase, with ensemble median increasing by the factor of 2.5 .

In the case of winter cereals, projected changes in area affected by SM deficits go in opposite directions for different ensemble members, regardless of RCP and future horizon (Fig. 7). Changes in the median area are rather low (usually not exceeding $20 \%$ of the historical values) compared to corresponding changes for other studied crops.

A different behaviour is projected for changes in the area cultivated by potato and maize, affected by SM excesses. Figure 8 illustrates the results for an "extreme" year (i.e. 95th percentile, as in Fig. 7), whereas Fig. 5 of Online Resource 1 shows inter-annual variability for each climate model. Most of the simulation runs show increasing area under moisture excess for RCP4.5 in the near future for both potato and maize and decreasing area for RCP8.5 in the far future (only for potato). In two remaining combinations (RCP8.5 in the near future and RCP4.5 in the far future), the magnitude of changes is generally lower, and their direction
Fig. 5 Box plots of projected changes in spatially averaged cumulative soil moisture deficits (CSMD) leading to crop yield losses for winter cereals (a), spring cereals (b), potato (c) and maize (d). Panels show box plots of the differences in the average of four highest CSMD values during the simulation period between the future and control runs, calculated across different ensemble members for four combinations of RCPs and future horizons. Positive values denote increasing SM deficits a

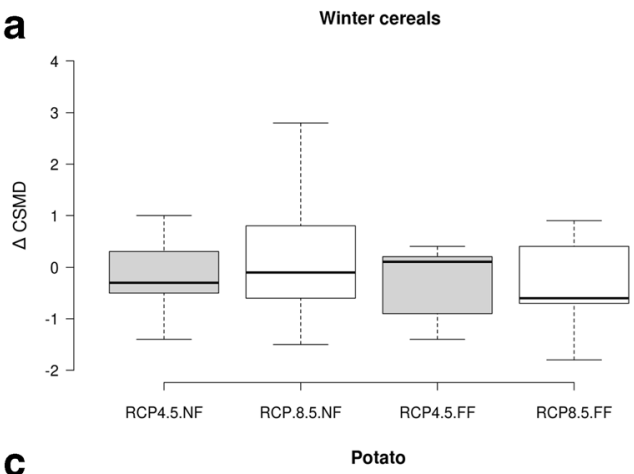

C

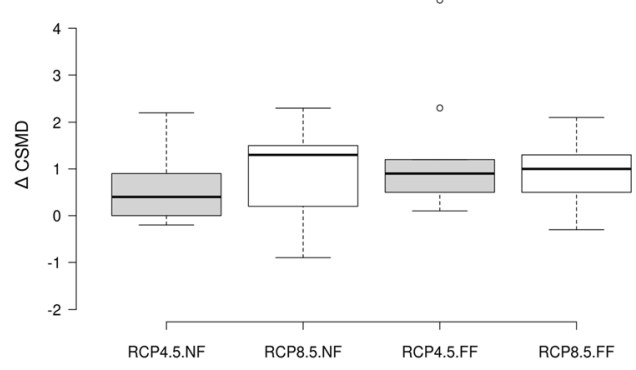

b

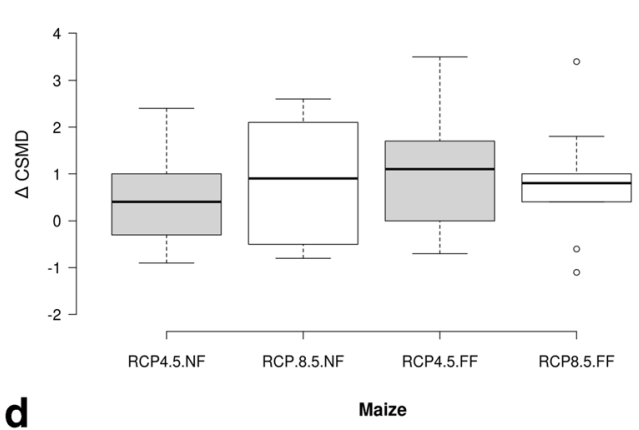

d

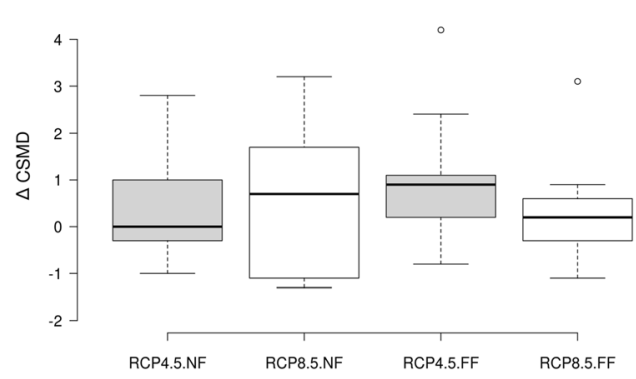


a

Potato
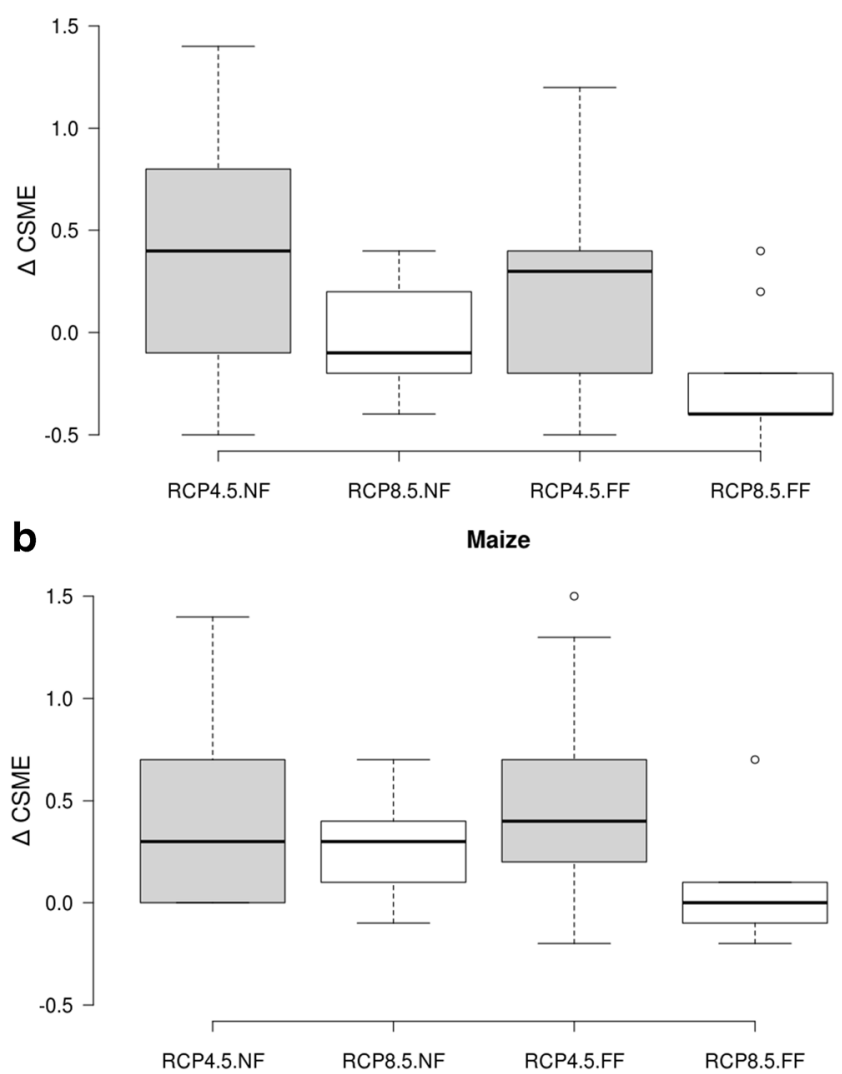

Fig. 6 Box plots of projected changes in spatially averaged cumulative soil moisture excess $(C S M E)$ leading to crop yield losses for potato (a) and maize (b). Panels show box plots of the differences in the average of two highest CSME values during the simulation period between the future and control runs calculated across different ensemble members for four combinations of RCPs and future horizons. Positive values denote increasing SM excess

varies across the ensemble. In each case, the multi-model median fractions of area affected by SM excess are generally lower than the corresponding fractions of area affected by SM deficit. A closer look into Fig. 5 of Online Resource 1 leads to a conclusion that the CSME values for potato and maize undergo an increase in the near future compared to the historical period for the majority of climate models, but then decrease in the far future.

\subsubsection{Spatial variability of changes in SM anomalies}

Spatial variability in projections of changes in cumulative soil moisture deficits (mean of the top four CSMD values) for different crops, RCP scenarios and future horizons is presented in Fig. 9. All maps show the ensemble median differences between future and control periods, and areas with lack of agreement on the direction of change (i.e. when less than two thirds models agreed) are greyed out. This lack of agreement is particularly well visible for winter and spring cereals. The difference between them is that for spring cereals, prevailing part of the remaining area shows a substantial increase in CSMD, whereas, in contrast, for winter cereals, a dominating decrease in CSMD is projected. For spring cereals, potato and maize, more negative changes are projected for the western part of Poland, particularly in the far future.

Although aggregating nine maps associated with nine climate models (cf. Table 2 of the Appendix A) into one map presenting the multi-model ensemble median is very convenient, it is useful to examine spatial variability in projected changes in CSMD for each of nine runs driven by different GCM-RCM combinations. As an example, Figs. 6 and 7 of Online Resource 1 present such maps for spring barley under RCP4.5 in the near future (Fig. 6) and under RCP8.5 in the far future (Fig. 7). These maps show clearly that spatial variability across different climate models is high and usually not consistent. This is particularly well visible for the eastern part of Poland under RCP4.5 in the near future, in which case three model runs (CM6-CM7, CM9) are showing prevailing increases in CSMD, two model runs (CM2-CM3) are showing prevailing decreases and four runs (CM1, CM4-CM5 and CM8) are showing mixed patterns. In consequence, this part of Poland is greyed out in Fig. 9 (spring cereals, RCP4.5 NF), thus illustrating the lack of consistency within the ensemble.

Projected changes in cumulative soil moisture excess (mean of the top two CSME values) for potato and maize, two RCP scenarios and two future horizons are shown in Fig. 10. In the case of potato, increases in CSME are projected in a large part of the country (except for east and south) for RCP4.5 in the near future. In three remaining RCP-horizon combinations, either the lack of agreement in projections is dominant or CSMD is projected to decrease. For maize, in all four combinations there are areas with decreases, increases and lack of agreement. As with potato, the largest agreement can be observed for RCP8.5 in the far future, in which extreme soil moisture excess conditions decrease in the majority of maize cultivation area.

\section{Discussion}

In this study, simulations of soil moisture anomalies during the crop critical development stages (and thus leading to crop losses) obtained with the help of the SWAT model were evaluated using empirical, station-based CWIs. Since the nature of CWIs is that they measure potential yield reductions without explicitly providing their causes, we used existing literature reporting weather-related crop yield losses in Poland in order to distinguish between SM deficit-related and SM excessrelated losses for four studied crops. The latter were much less frequent, both in simulations of SM anomalies using SWAT and in CWIs, which confirms that agricultural droughts are the principal natural factor reducing crop yields in Poland (Górski 
Fig. 7 Projections of the multiannual 95th percentile area ("extreme year") with SM deficit defined as a fraction of area occupied by a given crop with $C S M D$ exceeding the value of 3 . Box plots are calculated across nine ensemble members based on multi-annual mean areas for each simulation period (Hist - historical, NF - near future, $\mathrm{FF}$ - far future) and RCP
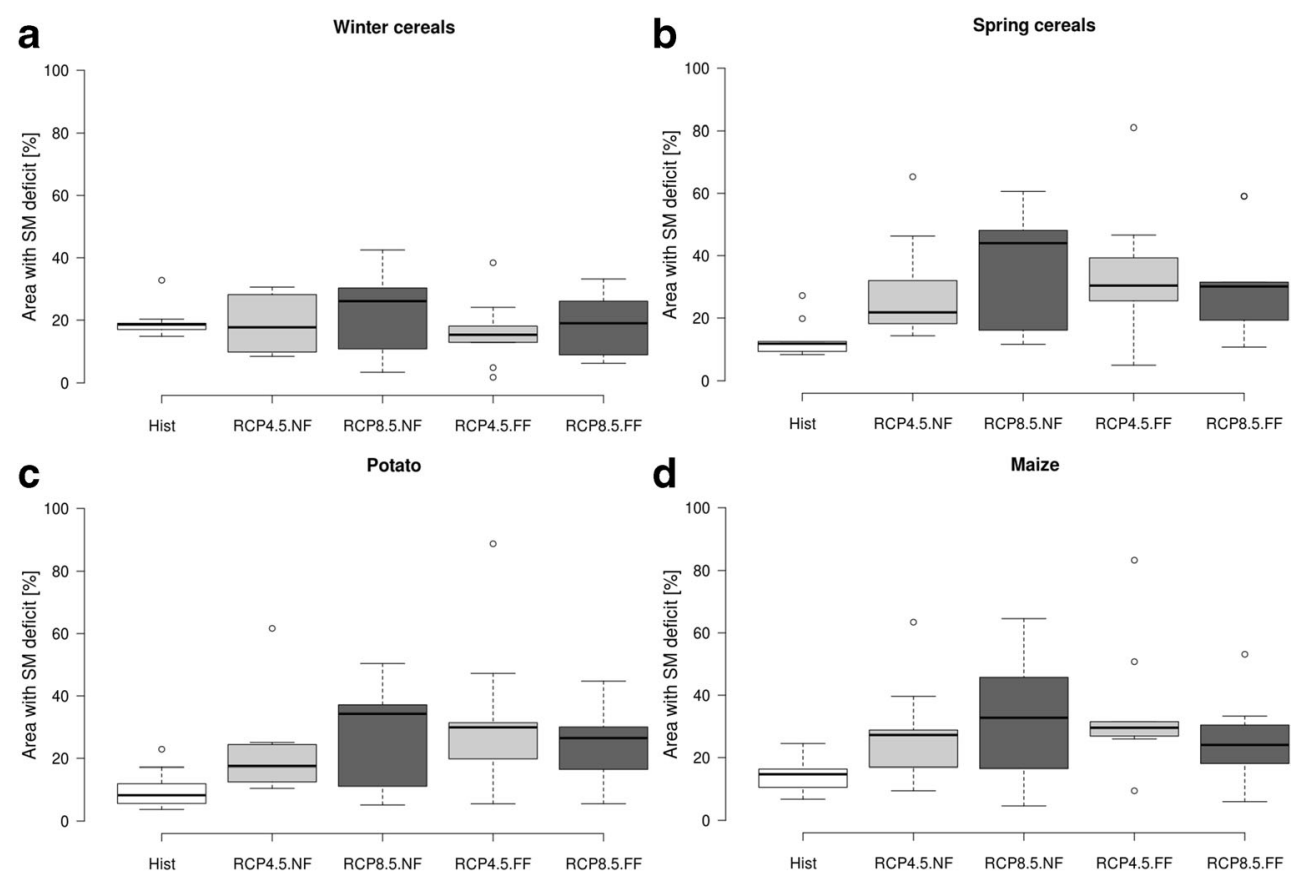

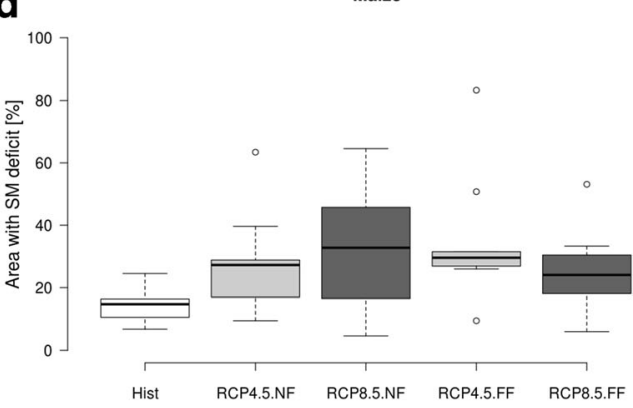

et al. 2008), although this is likely a more general finding, applicable also elsewhere (Boyer 1982; Wang et al. 2017).

Overall, a satisfactory level of agreement was found between CSMD/CSME and CWIs, both temporally and spatially. Some of the discrepancies were partly explained, e.g. the 1983 drought and the 1980 SM excess, whereas understanding of other particular extreme SM-related events would require more in-depth analysis that would be outside the scope of this study. It should be noted, though, that CWIs are not used here in order to validate simulations of soil moisture by SWAT, but just to compare these two similar types of outputs originating from different sources and based on different concepts. There are a few fundamental differences which make validation impossible: (1) CWIs incorporate wellestablished empirical knowledge on relationships between weather variables and crop yield and not all of them affect soil moisture; (2) CWIs include relationships for the most of the crop's growing season, while CSMD and CSME are restricted to development stages critical for SM requirements (Table 1); (3) There is a spatial discrepancy between stationbased CWIs and HRU-based SWAT indices; furthermore SWAT simulations of CSMD and CSME are soil propertiesdependent and may give different values for the same locations and weather conditions. However, this approach of indirect evaluation of a hydrological model is similar to the one used by Rudd et al. (2017) in their evaluation of the ability of the $\mathrm{G} 2 \mathrm{G}$ national-scale hydrological model of the UK to identify hydrological and soil moisture drought events in the historical period, 1891-2015. The purpose of such a loose comparison is to assess whether the model is able to capture major and moderate extreme events. As in Rudd et al.
(2017), the answer is positive. This enabled us to study the effect of climate change on SM anomalies.

a Potato
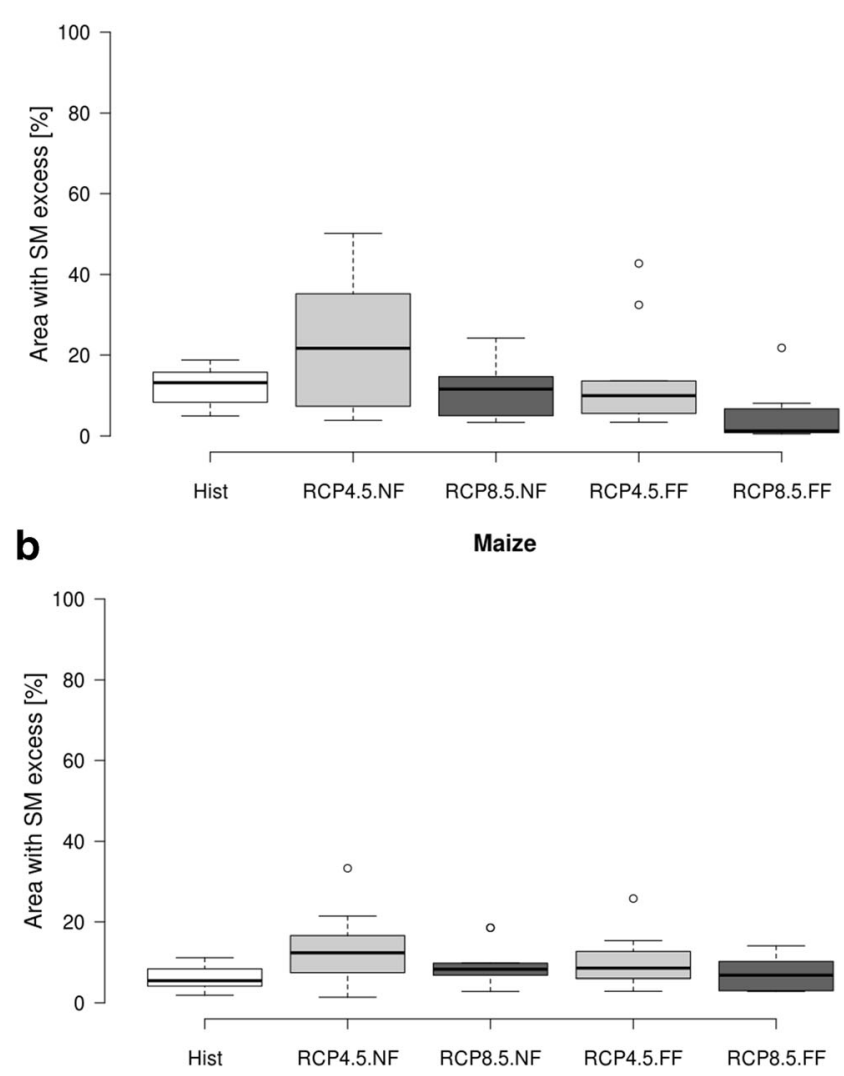

Fig. 8 Projections of the multi-annual 95th percentile area with SM excess defined as a fraction of area occupied by a given crop with CSME exceeding the value of 2. See Fig. 7 caption for more details 
Fig. 9 Projections of changes in cumulative soil moisture deficits $(C S M D)$ leading to crop yield losses for four selected crops, two RCPs and two time horizons. The maps show the ensemble medians of the differences in the average of four highest $C S M D$ values during the simulation period between the future and control runs. Grey overlay corresponds to areas for which the agreement on the direction of change (increase or decrease) is less than two thirds. White spaces are related to low fractions of a given crop in particular areas
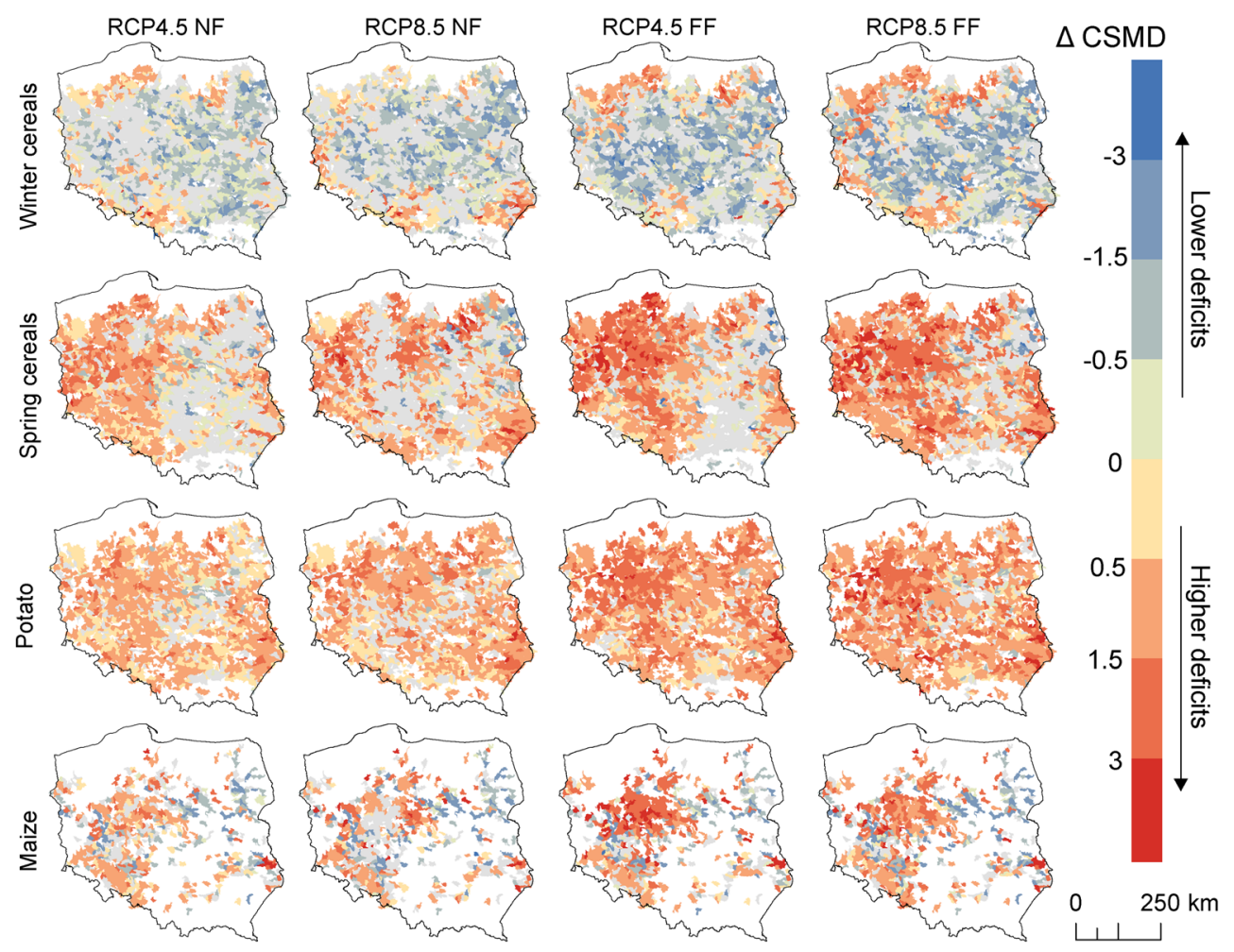

Projections of CSMD show that agricultural droughts may become more severe and affect larger area than in the historical reference period. This concerns mainly spring cereals, potato and maize, since the projected changes in severity and affected area for winter cereals are more uncertain: ensemble mean is close to zero, and different ensemble members show changes in different directions. Webber et al. (2018) also showed in their Europe-wide study that maize is likely to become more affected by future droughts, especially in low-yielding years, than winter wheat. The finding that SM deficits are expected to increase in the future may seem surprising given that the bias-corrected EURO-CORDEX projections used as forcing in SWAT assume considerably wetter conditions, with ensemble median increase in mean annual precipitation ranging between 5 and 19\% (Table 3; Piniewski et al. 2017a). Other studies using the same SWAT model setup for the Vistula and Odra basins demonstrated that high and low flows (Piniewski et al. 2017d) are also projected to increase. Two important differences should be noted, though. The assessment of SM deficits presented in this study (1) is restricted to the critical development stages defined between May and August for different crops (cf. Table 1); and (2) focuses on extreme rather than average conditions. As shown in Table 3 (Appendix A), ensemble mean precipitation increase in summer (JJA-June, July, August) is very low. In fact, some ensemble members feature a decrease in summer. In their analysis of precipitation projections from EUROCORDEX in Czech Republic (country neighbouring with Poland), Rulfová et al. (2017) demonstrated that the number of wet days in summer as well as a decrease in stratiform precipitation in this season are projected to decrease. They claim that this decrease, in combination with temperature increase, can lead to larger soil moisture deficits, and that projected more frequent and intense convective precipitation would not fully compensate because dry soils are not able to absorb all the water from intense precipitation events. Model-based evidence for these hypotheses was provided by Karlsson et al. (2015) and Wang et al. (2017). In their studies, quite similar shifts in seasonal precipitation were projected as in our study (i.e. high increases in winter, very low change in summer). Both reported that, in such conditions, agricultural drought indices (Karlsson et al. 2015) or drought stress (Wang et al. 2017) would be increasing and that this increase would be correlated with the level of climate warming.

Projections of CSME show that soil moisture excesses leading to crop losses may become more severe and occupy a larger area under RCP4.5 in the near future for potato and maize. In contrast, for RCP8.5 in the far future, the opposite change is projected, whereas in two remaining RCP-horizon combinations the results are more inconsistent. Such a pattern of change in CSME, the high-end RCP8.5 in the far future, 
Fig. 10 Projections of changes in cumulative soil moisture excess (CSME) leading to crop yield losses for two selected crops, two RCPs and two time horizons. The maps show the ensemble medians of the differences in the average of two highest CSME values during the simulation period between the future and control runs. See Fig. 9 caption for more details

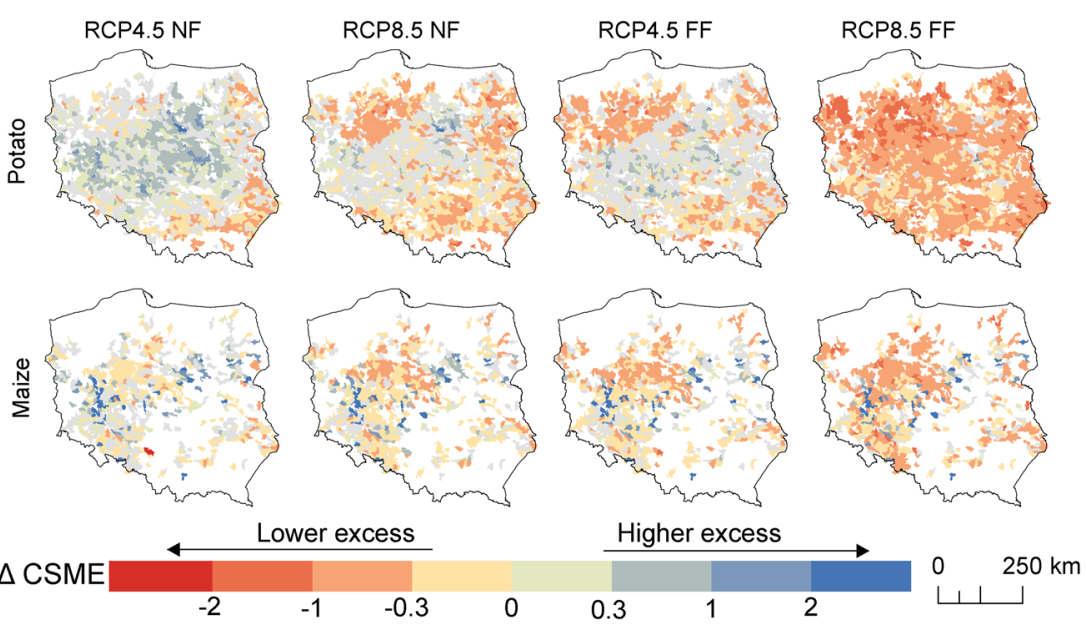

might be explained by the shifted critical development stages used for CSME computation in response to advanced crop phenological phases induced by the climate warming. Since SM content is typically higher in May and June than in July, there is a weaker chance of achieving high values of CSME when the critical development stage is advanced by 1 month.

Present study is, to our knowledge, the first one that provides state-of-the-art projections of future soil moisture anomalies that could trigger crop yield reductions in Poland, and thus it offers valuable insights into adaptation of Polish agriculture to the changing climate. However, care should be taken in direct use of these results, for several reasons. First of all, the uncertainty resulting from climate models is very large, and even if in some cases there is a good agreement on the direction of change, it is really hard to say what the magnitude will be. Such a situation is, however, quite common for climate impact studies using ensembles of climate models that often produce disparate results (Kundzewicz and Stakhiv 2010). Hence, a more important limitation is that our study presents "pure" effects of temperature and precipitation change on SM conditions (as a good proxy of crop yields), neglecting for instance direct effects of temperature (in particular heat stress), as well as complex, direct and indirect effects of elevated $\mathrm{CO}_{2}$ on yield. Although SWAT and its modified versions can take into account these effects (Wang et al. 2016; Butcher et al. 2014), when the Penman-Monteith method is used for PET simulation, lack of access to input data forced us to apply the Hargreaves method which does not enable quantification of the $\mathrm{CO}_{2}$ effect (cf. Piniewski et al. 2017c). Hence, our PET estimates are only driven by projected warming, whereas actual ET and SM projections by warming and precipitation change. On one hand, rising $\mathrm{CO}_{2}$ levels lead to reduced drought stress through decreased transpiration component of ET affected by reduced stomatal conductance of leaves, while on the other hand, they also lead to increased leaf biomass, generating a larger evaporative surface, which may fully or partly offset the increased water use efficiency, as shown at both the global (Lemordant et al. 2018) and the catchment (Butcher et al. 2014) levels. Consideration of $\mathrm{CO}_{2}$ fertilization effects has particularly high influence on wheat yield projections, leading to a positive change in yield in comparison to a negative change without the $\mathrm{CO}_{2}$ effect (Webber et al. 2018). While we are aware that our results would differ if complex effects of $\mathrm{CO}_{2}$ changes were taken into account, predicting this difference is not feasible without performing numerical experiments for this particular case study.

\section{Conclusions}

Results of this work lead to the following conclusions:

1. Temporal and spatial comparison of SWAT-based simulations of SM anomalies during the critical crop development stages with crop-weather indices proved that SWAT was capable of capturing episodes of major deficits and excesses of SM for different crops in Poland during the historical period. Simulations showed that SM deficits leading to crop losses occurred more frequently than SM excesses, which is in line with CWIs and literature. The proposed method of calculation of cumulative soil moisture deficits and excesses relying on time series of standardized SM and knowledge of regionspecific plant development stages with critical SM requirements is easily transferable elsewhere.

2. The results confirm that soil moisture-dependant not only on weather but also soil physical properties and 
quality - is a critical variable adding specific information that is not redundant with information encapsulated in meteorological variables, for prediction of yield variability in temperate climate (Peichl et al. 2018).

3. Despite a large model spread, projections generally show increasing severity of soil moisture deficits as well as of the area affected by them during extremely dry years, for spring cereals, potato and maize. The differences between RCPs and future horizons are generally lower than the inter-model spread, suggesting that selection of RCP is not a major source of uncertainty compared to selection of climate models. Hence, drought-related crop damages, such as those that occurred in Poland in 2015 and 2018, are likely to become more severe and affect larger areas than at present. This is particularly important given the fact that precipitation and runoff are projected to increase (although more in the winter season), according to the same set of climate projections (cf. Piniewski et al. 2017a, d).

4. The signals of change in soil moisture excesses for potato and maize are less straightforward, being more dependent on selection of RCP and future horizon: an increase (more severe excesses, and larger area affected) is projected for RCP4.5 in the near future, a decrease is projected for RCP8.5 in the far future, and changes in variable directions are simulated for the remaining two combinations.

Future work with the help of a process-based model, such as SWAT, should primarily focus on two aspects: (1) additionally taking into account temperature and $\mathrm{CO}_{2}$ fertilization effects on crop yield, which would give a more credible estimate of future crop yield in Poland; (2) scenario simulations addressing the question: how irrigation, drainage and other land and water management practices can help mitigate SM anomalies and thus reduce crop yield fluctuations on a sustainable basis (see Jägermeyr et al. 2016).

Acknowledgements The Institute of Meteorology and Water Management-National Research Institute (IMGW-PIB) of the Republic of Poland is kindly acknowledged for providing the hydro-meteorological data used in this work.

Funding information Financial support of the project CHASE-PL (Climate change impact assessment for selected sectors in Poland) of the Polish-Norwegian Research Programme operated by the National Centre for Research and Development (NCBiR) of Poland under the Norwegian Financial Mechanism 2009-2014 in the frame of Project Contract no. Pol Nor/200799/90/2014 is gratefully acknowledged. The first author is grateful for support of : (1) the National Science Centre for the project 2018/02/X/ST10/00205 "Modelowanie wpływu zmian klimatu na ekstremalne stany uwilgotnienia gleb prowadzące do spadków plonów w Polsce"; (2) the Alexander von Humboldt Foundation and (3) the Ministry of Science and Higher Education of the Republic of Poland. Joanna O'Keeffe was supported by ESSEM COST Action ES1308: Climate Change Manipulation Experiments in
Terrestrial Ecosystems-Networking and Outreach (ClimMani). Jerzy Kozyra was supported by the LCAgri project funded by the Polish National Centre for Research and Development (BIOSTRATEG1/ 271322/3/NCBR/2015).

\section{Appendix A Climate projections}

In this study we have used an ensemble of bias-corrected EUROCORDEX projections comprising two RCPs (4.5 and 8.5), two time horizons (2021-2050 and 2071-2100) and nine different combinations of 4 GCMs and 4 RCMs (Table 2). The bias in temperature and precipitation projections was corrected using the quantile mapping method as described by Mezghani et al. (2017).

Table 3 shows basic annual and seasonal statistics of projected changes in temperature and precipitation in the VOB. Spatially averaged annual mean temperature was expected to increase by $1.1-1.3{ }^{\circ} \mathrm{C}$ for the near future and $2.0-3.6{ }^{\circ} \mathrm{C}$ for the far future, depending on the RCP scenario (ensemble mean). Higher warming rate was projected for RCP8.5 than for RCP4.5. The magnitude of increase varied seasonally, with the maximum achieved in winter for all future horizons and RCPs. Projections of annual and seasonal precipitation $(P)$ totals based on the ensemble mean showed less consistent signals than those of temperature, even though the climate models consistently indicated increase of the areal mean $P$. Changes were greater for higher RCP and later projection horizon, varying from 5.5\% under RCP 4.5 in the near future to $16.2 \%$ under RCP 8.5 in the far future. Seasonally, the highest increases were projected for winter and spring, although high model spread reduced considerably the robustness. The ensemble members agreed well that, overall, precipitation in summer and autumn seasons will not undergo statistically significant changes.

Table 2 The list of used EURO-CORDEX climate simulations (GCMRCM combinations) composing the multi-model ensemble. Each combination was available for the historical period (1971-2000) and two future periods (2021-2050 and 2071-2100) under two RCPs (4.5 and 8.5)

\begin{tabular}{lll}
\hline Code & GCM & RCM \\
\hline 01 & CNRM-CERFACS-CNRM-CM5 & CLMcom-CCLM4-8-17 \\
02 & CNRM-CERFACS-CNRM-CM5 & SMHI-RCA4 \\
03 & ICHEC-EC-EARTH & CLMcom-CCLM4-8-17 \\
04 & ICHEC-EC-EARTH & SMHI-RCA4 \\
05 & ICHEC-EC-EARTH & KNMI-RACMO22E \\
06 & ICHEC-EC-EARTH & DMI-HIRHAM5 \\
07 & IPSL-IPSL-CM5A-MR & SMHI-RCA4 \\
08 & MPI-M-MPI-ESM-LR & CLMcom-CCLM4-8-17 \\
09 & MPI-M-MPI-ESM-LR & SMHI-RCA4 \\
\hline
\end{tabular}


Table 3 Multi-model ensemble median projections of change in annual and seasonal means of daily minimum $\left(T_{\min }\right)$ and maximum $\left(T_{\max }\right)$ temperatures and precipitation $(P)$ calculated across the whole VOB (after Piniewski et al. 2017a)

\begin{tabular}{|c|c|c|c|c|c|c|c|c|c|c|c|}
\hline \multirow[t]{2}{*}{ Variable } & \multirow[t]{2}{*}{ Horizon } & \multicolumn{5}{|l|}{$\mathrm{RCP} 4.5$} & \multicolumn{5}{|l|}{ RCP 8.5} \\
\hline & & Annual & DJF & MAM & JJA & SON & Annual & DJF & MAM & JJA & SON \\
\hline \multirow[t]{2}{*}{$T_{\min }\left[{ }^{\circ} \mathrm{C}\right]$} & $\mathrm{NF}$ & 1.2 & 1.4 & 1.0 & 1.1 & 1.2 & 1.5 & 1.7 & 1.4 & 1.3 & 1.5 \\
\hline & $\mathrm{FF}$ & 2.2 & 2.9 & 2.2 & 1.7 & 1.9 & 3.7 & 4.8 & 3.4 & 3.4 & 3.6 \\
\hline \multirow[t]{2}{*}{$T_{\max }\left[{ }^{\circ} \mathrm{C}\right]$} & NF & 1.0 & 1.2 & 0.8 & 0.9 & 1.1 & 1.1 & 1.4 & 1.2 & 1.0 & 1.3 \\
\hline & $\mathrm{FF}$ & 1.8 & 2.3 & 1.9 & 1.5 & 1.9 & 3.3 & 4.4 & 3.0 & 2.8 & 3.5 \\
\hline \multirow[t]{2}{*}{$P[\%]$} & $\mathrm{NF}$ & 5.5 & 7.3 & 9.8 & 1.5 & 1.4 & 7.9 & 10.1 & 12.5 & 2.7 & 2.3 \\
\hline & $\mathrm{FF}$ & 9.3 & 13.0 & 19.9 & 2.1 & 1.5 & 16.2 & 24.6 & 27.9 & 2.7 & 9.1 \\
\hline
\end{tabular}

\section{Appendix B Calculation method of soil moisture indicators}

Daily varying thresholds for occurrence of soil moisture deficit or excess conditions were defined as follows:

$$
\begin{aligned}
& T V T_{i}^{-}=\mu_{i}-X \cdot \sigma_{i}, \\
& T V T_{i}^{+}=\mu_{i}+X \cdot \sigma_{i},
\end{aligned}
$$

where $T V T_{i}^{-}$and $T V T_{i}^{+}$are time-variable thresholds for occurrence of SM deficit and excess for day $i$, respectively; $\mu_{i}$ and $\sigma_{i}$ are the values of long-term mean and standard deviation of SM content for day $i$; while $X$ is a soil-specific multiplier accounting for variable retention properties of soils. The values of $X$ (Table 4) were set with reference to the conventional classification of soil texture in Poland used in the Agricultural Drought Monitoring System by IUNG-PIB (Doroszewski et al. 2012).

$$
\begin{aligned}
& C S M D_{j}= \begin{cases}\sum_{i \in C D S}\left(T V T_{i}^{-}-z_{i, j}\right) & \text { if } \quad T V T_{i}^{-}-z_{i, j} \geq 0\end{cases} \\
& C S M E_{j}= \begin{cases}\sum_{i \in C D S}\left(z_{i, j}-T V T_{i}^{+}\right) & \text {if } \quad z_{i, j}-T V T_{i}^{+} \geq 0\end{cases}
\end{aligned}
$$

Table 4 The values of multiplier $X$ for different soil texture groups

\begin{tabular}{llll}
\hline Soil (texture) group & Example soils & Deficit & Excess \\
\hline Very light & Sand & 1 & 1.6 \\
Light & Loamy sand & 1.2 & 1.4 \\
Moderate & Sandy loam, silts & 1.4 & 1.2 \\
Heavy & Sandy clay loam, loam, & 1.6 & 1 \\
& \multicolumn{2}{c}{ clay loam, silt loam, clay } & \\
\hline
\end{tabular}

The cumulative soil moisture deficit $\left(C S M D_{j}\right)$ and excess $\left(C S M E_{j}\right)$ indicators were developed that quantify the magnitude of drought and water excess conditions in soils for each year of the simulation period $j$ :

$$
\begin{aligned}
& \text { if } \quad T V T_{i}^{-}-z_{i, j}<0 \\
& \text { if } \quad z_{i, j}-T V T_{i}^{+}<0
\end{aligned}
$$

where $C D S$ is the crop-specific critical development stage (Table 1), and $z_{i, j}$ is the simulated (normalized) SM content for year $j=1, \ldots, 27$ and day $i \in C P$. Graphical illustration of CSMD and CSME was shown in Fig. 2.

Open Access This article is licensed under a Creative Commons Attribution 4.0 International License, which permits use, sharing, adaptation, distribution and reproduction in any medium or format, as long as you give appropriate credit to the original author(s) and the source, provide a link to the Creative Commons licence, and indicate if changes were made. The images or other third party material in this article are included in the article's Creative Commons licence, unless indicated otherwise in a credit line to the material. If material is not included in the article's Creative Commons licence and your intended use is not permitted by statutory regulation or exceeds the permitted use, you will need to obtain permission directly from the copyright holder. To view a copy of this licence, visit http://creativecommons.org/licenses/by/4.0/.

\section{References}

Andreadis KM, Clark EA, Wood A, Hamlet AF, Lettenmaier DP (2006) Twentieth-century drought in the conterminous United States. J Hydrometeorol 6:985-1001. https://doi.org/10.1175/JHM450.1

Arnold JG, Srinivasan R, Muttiah RS, Williams JR (1998) Large area hydrologic modelling and assessment part I: model development. J Am Water Resour Assoc 34:73-89. https://doi.org/10.1111/j.17521688.1998.tb05961.x

Bański J (Ed.) (2010) Atlas rolnictwa Polski. PAN IGiPZ, Warszawa https://www.igipz.pan.pl/atlas-rolnictwa-polski-zgwirl.html (accessed 20.11.2018) 
Boyer JS (1982) Plant productivity and environment. Science 218:443448. https://doi.org/10.1126/science.218.4571.443

Brown IM (2017) Climate change and soil wetness limitations for agriculture: spatial risk assessment framework with application to Scotland. Geoderma 285:173-184. https://doi.org/10.1016/j. geoderma.2016.09.023

Butcher JB, Johnson TE, Nover D, Sarkar S (2014) Incorporating the effects of increased atmospheric $\mathrm{CO} 2$ in watershed model projections of climate change impacts. J Hydrol 513:322-334. https://doi. org/10.1016/j.jhydrol.2014.03.073

Doroszewski A, Jadczyszyn J, Kozyra J, Pudełko R, Stuczyński T, Mizak $\mathrm{K}$ et al (2012) Podstawy systemu monitoringu suszy rolniczej. Woda-Środowisko-Obszary Wiejskie 12(2):77-79

Earl HJ, Davis RF (2003) Effect of drought stress on leaf and whole canopy radiation use efficiency and yield of maize. Agron J 95: 688-696. https://doi.org/10.2134/agronj2003.6880

Farat R, Kępińska-Kasprzak M, Kowalczak P, Mager P (1998) Droughts in Poland, 1951-90. Drought Network News (1994-2001). Vol. 10, No. 1, Paper 42

Farooq M, Hussain M, Siddique KHM (2014) Drought stress in wheat during flowering and grain-filling periods. Crit Rev Plant Sci 33(4): 331-349. https://doi.org/10.1080/07352689.2014.875291

Górski T (2007) Changes in Poland's agroclimatic conditions over the last century. Papers on Global Change 14:55-67

Górski T, Kozyra J, Doroszewski A (2008) Field crop losses in Poland due to extreme weather conditions - case studies. In: Liszewski S (ed) The influence of extreme phenomena on the natural environment and human living conditions. Łódzkie Towarzystwo Naukowe, Łódź, pp 35-49

Grzebisz W (2011a) Technologia nawożenia roślin uprawnychfizjologia plonowania-Zboża i kukurydza. Tom 1. PWRiL, Poznań, p 284

Grzebisz W (2011b) Technologia nawożenia roślin uprawnychfizjologia plonowania-Zboża i kukurydza. Tom 2. PWRiL, Poznań, p 284

Hane DC, Pumphrey FV (1984) Crop water use curves for irrigation scheduling. Special report 706, Agricultural Experiment Station, Oregon State University, Corvallis

Hoy A, Hänsel S, Skalak P, Ustrnul Z, Bochníček O (2017) The extreme European summer of 2015 in a long-term perspective. Int J Climatol 37:943-962. https://doi.org/10.1002/joc.4751

Jägermeyr J, Gerten D, Schaphoff S, Heinke J, Lucht W, Rockström J (2016) Integrated crop water management might sustainably halve the global food gap. Environ Res Lett 11(2):025002. https://doi.org/ $10.1088 / 1748-9326 / 11 / 2 / 025002$

Kalbarczyk R (2004) Czasowy i przestrzenny rozkład głównych czynników agrometeorologicznych istotnie kształtujących plony ziemniaka w Polsce. Przegląd Naukowy IiKŚ XIII 2(29):168-178

Karlsson IB, Sonnenborg TO, Seaby LP, Jensen KH, Refsgaard JC (2015) Effect of a high-end $\mathrm{CO}_{2}$-emission scenario on hydrology. Clim Res 64:39-54. https://doi.org/10.3354/cr01265

Koźmiński C (1994) Określanie i prognozowanie pozimowych zapasów wody w glebie lekkiej na podstawie elementów meteorologicznych. Rocz AR Pozn Melior Inż Środ 13:33-49

Koźmiński C (1996) Uwilgotnienie gleby pod oziminami i ziemniakami w województwie koszalińskim. Zesz Nauk AR Szczecin 174(64): 165-177

Koźmiński C, Michalska B (1995) Atlas uwilgotnienia gleby w Polsce. AR, Szczecin, p 1995

Kozyra J, Nieróbca A, Mizak K, Pudełko R, Świtaj Ł, Kozak M (2012) Diagnoza i prognoza warunków produkcji rolniczej w Polsce w wyniku oddziaływania ekstremalnych zjawisk meteorologicznych i hydrologicznych. In: Wpływ zmian klimatu na środowisko, gospodarkę i społeczeństwo. Zmiany, skutki i sposoby ich ograniczenia, wnioski dla nauki, praktyki inżynierskiej i planowania gospodarczego, Vol. 3, Klęski żywiołowe a bezpieczeństwo wewnętrzne kraju. IMGW-PIB, Warszawa, 265-277

Królczyk JB, Latawiec AE, Kuboń M (2014) Sustainable agriculturethe potential to increase wheat and rapeseed yields in Poland. Pol J Environ Stud 23(3):663-672 ISSN 1230-1485

Kundzewicz ZW, Stakhiv EZ (2010) Are climate models "ready for prime time" in water resources management applications, or is more research needed? Editorial Hydrol Sci J 55(7):1085-1089. https://doi. org/10.1080/02626667.2010.513211

Łabędzki L (2007) Estimation of local drought frequency in central Poland using the standardized precipitation index SPI. Irrig and Drain 56:67-77. https://doi.org/10.1002/ird.285

Lemordant L, Gentine P, Swann AS, Cook BI, Scheff J (2018) Critical impact of vegetation physiology on the continental hydrologic cycle in response to increasing $\mathrm{CO}_{2}$. Proc Natl Acad Sci U S A. https://doi. org/10.1073/pnas.1720712115

Li P, Omani N, Chaubey I, Wei X (2017) Evaluation of drought implications on ecosystem services: freshwater provisioning and food provisioning in the Upper Mississippi River basin. Int J Environ Res Public Health 14(5):496. https://doi.org/10.3390/ijerph14050496

Lu J, Carbone GJ, Gao P (2017) Detrending crop yield data for spatial visualization of drought impacts in the United States, 1895-2014. Agric For Meteorol 237-238:196-208. https://doi.org/10.1016/j. agrformet.2017.02.001

Malik AI, Colmer TD, Lambers H, Setter TL, Schortemeyer M (2002) Short-term waterlogging has long-term effects on the growth and physiology of wheat. New Phytol 153:225-236. https://doi.org/10. 1046/j.0028-646X.2001.00318.x

Marcinkowski P, Piniewski M (2018) Effect of climate change on sowing and harvest dates of spring barley and maize in Poland. International Agrophysics 32(2):265-271. https://doi.org/10.1515/intag-20170015

Martyniak L (2012) Wskaźniki reakcji zbóż jarych na stres wodny w poszczególnych fazach ich wzrostu i rozwoju. Falenty. Wydaw. ITP. ISBN 83-88763-46-6 ss. 60

McWilliams D (2002) Drought strategies for corn and grain sorghum. Coop Ext. Circ. 580, New Mexico State Univ., Las Cruces, NM

Meier U, Bleiholder H, Buhr L, Feller C, Hack H, Heß M et al (2009) The $\mathrm{BBCH}$ system to coding the phenological growth stages of plantshistory and publications. J Kulturpflanzen 61(2):41-52 ISSN $0027-$ 7479

Meresa HK, Osuch M, Romanowicz R (2016) Hydro-meteorological drought projections into the 21-st century for selected Polish catchments. Water 8:206. https://doi.org/10.3390/w8050206

Mezghani A, Dobler A, Haugen JE, Benestad RE, Parding KM, Piniewski M et al (2017) CHASE-PL climate projection dataset over Poland-bias adjustment of EURO-CORDEX simulations. Earth Syst Sci Data 9:905-925. https://doi.org/10.5194/essd-9-905-2017

Narasimhan B, Srinivasan R (2005) Development and evaluation of soil moisture deficit index (SMDI) and evapotranspiration deficit index (ETDI) for agriculture drought monitoring. Agric For Meteorol 133: 69-88. https://doi.org/10.1016/j.agrformet.2005.07.012

Neitsch S, Arnold J, Kiniry J, Williams J (2011) Soil and water assessment tool - theoretical documentation. Technical Report TR-406, Texas A\&M University

Nix HA, Fitzpatrick EA (1969) An index of crop water stress related to wheat and grain sorghum yields. Agric Meteorol. 6(5):321-337. https://doi.org/10.1016/0002-1571(69)90024-7

Pagani V, Guarneri T, Fumagalli D, Movedi E, Testi L, Klein T et al (2017) Improving cereal yield forecasts in Europe - the impact of weather extremes. Eur J Agron 89:97-106. https://doi.org/10.1016/ j.eja.2017.06.010

Peichl M, Thober S, Meyer V, Samaniego L (2018) The effect of soil moisture anomalies on maize yield in Germany. Nat Hazards Earth Syst Sci 18:889-906 
Piniewski M, Mezghani A, Szcześniak M, Kundzewicz ZW (2017a) Regional projections of temperature and precipitation changes: robustness and uncertainty aspects. Meteorol Z. https://doi.org/10. $1127 /$ metz/2017/0813

Piniewski M, Szcześniak M, Kardel I (2017b) CHASE-PL-future hydology data set: projections of water balance and streamflow for the Vistula and Odra basins, Poland. Data 2(2):14. https://doi.org/10. 3390/data2020014

Piniewski M, Szcześniak M, Kardel I, Berezowski T, Okruszko T, Srinivasan R et al (2017c) Hydrological modelling of the Vistula and Odra river basins using SWAT. Hydrol Sci J. https://doi.org/10. 1080/02626667.2017.1321842

Piniewski M, Szcześniak M, Kundzewicz ZW, Mezghani A, Hov Ø (2017d) Changes in low and high flows in the Vistula and the Odra basins: model projections in the European-scale context. Hydrol Process. https://doi.org/10.1002/hyp.11176

Raes D, Geerts S, Kipkorir E, Wellens J, Sahli A (2006) Simulation of yield decline as a result of water stress with a robust soil water balance model. Agric Water Manage 81(3):335-357. https://doi. org/10.1016/j.agwat.2005.04.006

Ray DK, Gerber JS, MacDonald GK, West PC (2015) Climate variation explains a third of global crop yield variability. Nat Commun 6. https://doi.org/10.1038/ncomms6989

Rosenzweig C, Tubiello FN, Goldberg R, Mills E, Bloomfield J (2002) Increased crop damage in the US from excess precipitation under climate change. Global Environ Chang 12:197-202. https://doi.org/ 10.1016/S0959-3780(02)00008-0

Rudd AC, Bell VA, Kay AL (2017) National-scale analysis of simulated hydrological droughts (1891-2015). J Hydrol 550:368-385. https:// doi.org/10.1016/j.jhydrol.2017.05.018

Rulfová Z, Beranová R, Kyselý J (2017) Climate change scenarios of convective and large-scale precipitation in the Czech Republic based on EURO-CORDEX data. Int J Climatol 37:2451-2465. https://doi. org/10.1002/joc. 4857

Samaniego L, Kumar R, Zink M (2013) Implications of parameter uncertainty on soil moisture drought analysis in Germany. J Hydrometeorol 14:47-68. https://doi.org/10.1175/JHM-D-12-075.1

Samaniego L, Thober S, Kumar R, Wanders N, Rakovec O, Pan M et al (2018) Anthropogenic warming exacerbates European soil moisture droughts. Nat Clim Chang 8:421-426. https://doi.org/10.1038/ s41558-018-0138-5

Schauberger B, Rolinski S, Müller C (2016) A network-based approach for semi-quantitative knowledge mining and its application to yield variability. Environ Res Lett 11(12):123001. https://doi.org/10. 1088/1748-9326/11/12/123001

Schauberger B, Archontoulis S, Arneth A, Balkovic J, Ciais P, Deryng D et al (2017) Consistent negative response of US crops to high temperatures in observations and crop models. Nat Commun 8:13931. https://doi.org/10.1038/ncomms 13931

Somorowska U (2016) Changes in drought conditions in Poland over the past 60 years evaluated by the Standardized Precipitation-
Evapotranspiration Index. Acta Geophys 64:2530-2549. https:// doi.org/10.1515/acgeo-2016-0110

Somorowska U (2017) Soil water storage in Poland over the years 20002015 in response to precipitation variability as retrieved from GLDAS NOAH simulations. Geogr Pol 90(1):53-64. https://doi. org/10.7163/GPol.0078

Spinoni J, Naumann G, Vogt JV, Barbosa P (2015) The biggest drought events in Europe from 1950 to 2012. J Hydrol: Reg Stud 3:509-524. https://doi.org/10.1016/j.ejrh.2015.01.001

Srinivasan R, Zhang Q, Arnold J (2010) SWAT ungauged: hydrological budget and crop yield predictions in the Upper Mississippi River basin. Trans ASABE 53(5):1533-1546

Trnka M, Balek J, Štěpánek P, Zahradníček P, Možný M, Eitzinger J et al (2016) Drought trends over part of Central Europe between 1961 and 2014. Clim Res 70:143-160. https://doi.org/10.3354/cr01420

Urban DW, Roberts MJ, Schlenker W, Lobell DB (2015) The effects of extremely wet planting conditions on maize and soybean yields. Clim Chang 130:247-260. https://doi.org/10.1007/s10584-0151362-x

Van Lanen HAJ, Laaha G, Kingston DG, Gauster T, Ionita M et al (2016) Hydrology needed to manage droughts: the 2015 European case. Hydrol Process 30:3097-3104. https://doi.org/10.1002/hyp.10838

Van Loon CD (1981) The effect of water stress on potato growth, development and yield. Am Potato J 58:51-69. https://doi.org/10.1007/ BF02855380

Wang R, Bowling LC, Cherkauer KA (2016) Estimation of the effects of climate variability on crop yield in the Midwest USA. Agric For Meteorol 216:141-156. https://doi.org/10.1016/j.agrformet.2015. 10.001

Wang R, Bowling LC, Cherkauer KA, Cibin R, Her Y, Chaubey I (2017) Biophysical and hydrological effects of future climate change including trends in $\mathrm{CO} 2$, in the St. Joseph River watershed, Eastern Corn Belt. Agric Water Manage 180(Part B):280-296. https://doi. org/10.1016/j.agwat.2016.09.017

Webber H, Ewert F, Olesen JE, Müller C, Fronzek S, Ruane AC (2018) Diverging importance of drought stress for maize and winter wheat in Europe. Nat Commun 9:4249. https://doi.org/10.1038/s41467018-06525-2

Williams JR, Renard KG, Dyke PT (1982) EPIC - a new model for assessing erosion's effect on soil productivity. J Soil Water Conserv 38(5):381-383

Zawadzki W, Mierosławska A (1993) Susze glebowe a produkcja roślinna w Polsce. Problemy gospodarowania wodą w rolnictwie w świetle suszy 1992 roku. Mat. Sem. 33. Wyd. IMUZ, Falenty, 143-159

Publisher's note Springer Nature remains neutral with regard to jurisdictional claims in published maps and institutional affiliations. 